\title{
Impact of a river flash flood on microbial carbon and nitrogen production in a Mediterranean Lagoon (Thau Lagoon, France)
}

\author{
E. Fouilland ${ }^{a, *}$, A. Trottet ${ }^{a, 1}$, C. Bancon-Montigny ${ }^{b}$, M. Bouvy ${ }^{a}$, E. Le Floc' $h^{c}$, J.-L. Gonzalez ${ }^{d}$ \\ E. Hatey ${ }^{a}$, S. Mas ${ }^{c}$, B. Mostajir ${ }^{\mathrm{a}, c}$, J. Nouguier $^{\mathrm{a}}$, D. Pecqueur ${ }^{\mathrm{a}}$, E. Rochelle-Newall ${ }^{\mathrm{e}}$, C. Rodier ${ }^{\mathrm{b}}$, \\ C. Roques ${ }^{a}$, C. Salles ${ }^{b}, M .-G$. Tournoud ${ }^{b}$, F. Vidussi $^{a}$
}

\begin{abstract}
a Laboratoire Ecologie des Systèmes Marins Côtiers, UMR 5119 ECOSYM (Université Montpellier 2, CNRS, IRD, IFREMER, Université Montpellier 1), Université Montpellier 2, Place E. Bataillon, CC093, F-34095 Montpellier and Station Méditerranéenne de l'Environnement Littoral, 2 rue des Chantiers, F-34200 Sète, France

${ }^{\mathrm{b}}$ Laboratoire HydroSciences, UMR 5569 (CNRS, IRD, UM1, UM2), Université Montpellier II, case courrier 057, F34095 Montpellier cedex 5, France

${ }^{c}$ Centre d'écologie marine expérimentale MEDIMEER (Mediterranean center for Marine Ecosystem Experimental Research), UMS 3301, Université Montpellier 2, CNRS, Station Méditerranéenne de l'Environnement Littoral, MEDIMEER, 2 rue des Chantiers, F-34200 Sète, France

d IFREMER, Département Biogéochimie \& Ecotoxicologie, La Seyne/Mer, France

e IRD-BIOEMCO, UMR 7618, 46 rue d'UIm, F-75230 Paris CEDEX 05, France
\end{abstract}

1 Present address: DHI Water \& Environment (S) Pte Ltd, 200 Pandan Loop, \#08-03 Pantech 21, Singapore 128388.

*: Corresponding author : Eric Fouilland, email address : Eric.Fouilland@univ-montp2.fr

\begin{abstract}
:
Over half of the total nitrogen, phosphorus, silicate and dissolved organic carbon (DOC) loading was discharged from the Vène River into the Thau Lagoon waters within the first five days of what was considered to be the autumn flash flood period. Such loads represented about $8 \%$ and $3 \%$ of the yearly averaged total nitrogen and phosphorus load in Thau Lagoon, respectively. Although this event affected $>20 \%$ of the total lagoon volume, river trace metal loads contributed apparently only weakly to the increase in labile trace metal concentrations in the lagoon surface waters. Differences between theoretical dilution values and observed values were also noticed for phosphate, silicate and dissolved organic carbon (DOC) concentrations. DOC losses (10-50\%) mainly through flocculation, together with the substantial increases in some metallic contaminants such as $\mathrm{Zn}$ (from 6 to $>30 \mu \mathrm{g} \mathrm{L}^{-1}$ ) observed during the flash flood in saline lagoon waters, may have limited the carbon production of bacterial communities. The potential osmotic shock and the increase in turbidity may mainly explain the low phytoplankton $C$ turnover rates (average of $0.02 \mathrm{~h}^{-1}$ ) measured in brackish waters $(<30)$ during periods of heavy flood discharge. The dissolved inorganic nitrogen (DIN: $\mathrm{NO}_{3}+\mathrm{NH}_{4}$ ) enrichment measured 12 days after the flash flood event in saline lagoon surface waters (from 22 to $143 \mu \mathrm{g} \mathrm{L}^{-1}$ ) led to a substantial increase in phytoplanktonic $\mathrm{C}$ production and associated DIN uptake rates (from 2.6 to $7.0 \mu \mathrm{g} \mathrm{C} \mathrm{L}^{-1} \mathrm{~h}^{-1}$ and from 0.5 to $1.1 \mu \mathrm{g} \mathrm{L}^{-1} \mathrm{~h}^{-1}$, respectively). Subsequent accumulation in particulate organic carbon and nitrogen was not observed in the area studied during and after the flash flood period, averaging $549 \pm 50 \mu \mathrm{C} \mathrm{L}^{-1}$ and $168 \pm 9 \mu \mathrm{g} \mathrm{N} \mathrm{L}^{-1}$, respectively. This suggests that most of locally produced microbial production was rapidly filtered by oysters contributing to about $13 \%$ of the yearly exploited production in the lagoon and/or exported through sedimentation.
\end{abstract}

\section{Highlights}

- Flash flood discharges were $8 \%$ and $3 \%$ of the yearly averaged total nitrogen and phosphorus loads. Substantial increase of labile trace metals in lagoon waters was not mainly due to river loads. Bacterial production was limited by the reduction in DOC availability during the flood event. DIN enrichments was beneficial for the production of the most resilient lagoon phytoplankton. The enhanced microbial production was mainly filtered or exported through sedimentation.

Keywords: river discharge ; phytoplankton and bacteria production ; DIN uptake rates ; metal contaminants ; Mediterranean coastal waters 


\section{Introduction}

River floods are important processes in the land to sea transfer of dissolved and particulate matter and associated contaminants (e.g. trace metals). A large fraction of riverine discharges occurs during flash flood events in the Mediterranean coastal zone (Cherifi \& Loudiki 1999, Tournoud et al 2006, Chu et al 2008). This type of event is caused by extreme meteorological conditions and is characterized by short, intense flood events lasting for a few hours or days. Such short, intense discharge from Mediterranean rivers produces more than half of the annual suspended material and brings significant nitrogen inputs $(40-80 \%$ of annual total nitrogen loads) into semi-closed coastal areas such as lagoons (Velasco et al 2006, Tournoud et al 2006, Gouze et al 2008). Flash floods may also contribute significantly to the discharge of contaminants (e.g., pathogens, metals, xenobiotics), particularly in these areas which have low monthly rainfall. Chu et al (2011) reported that a single major flood accounted on average for $74 \%$ of the total annual load of thermotolerant coliforms over a 12 year sampling period in two northern Mediterranean coastal rivers flowing into Thau Lagoon (France). Furthermore, during a rainfall period the concentrations of two major trace metals, zinc $(\mathrm{Zn})$ and lead $(\mathrm{Pb})$, increased by factors of 4 and 10, respectively, in the Vène River, the main contributor of freshwater to the Thau Lagoon (Monna et al 1995).

Little is known about the direct effect of flash floods on coastal waters, mainly because they are episodic and unpredictable. Significant increases in primary production are generally observed during and after such events in enclosed or semi-enclosed coastal areas (Troussellier \& Deslous-Paoli 2001, Harzallah \& Chapelle 2002, Velasco et al 2006) and in more open areas such as bays (Guizien et al 2007). Modelling has suggested that the positive effect of river discharges on primary producers (phytoplankton and macrophytes) is restricted mainly to the areas close to the river outlets (Plus et al 2006) and this has been confirmed by some experimental observations (Velasco et al 2006, Guizien et al 2007). Recently, Pecqueur et al (2011) showed that the biomass of phytoplankton (mainly Bacillariophyceae, Cryptophyceae and Chlorophyceae) and bacteria significantly increased in the Mediterranean surface waters of the Thau Lagoon during an autumnal flash flood event. However, the same river flood had a also a negative effect on the Dinophyceae, Prasinophyceae and Prymnesiopyceae groups. These observations suggest that phytoplankton coming from the floodwaters contributed mainly to the biomass accumulation in the lagoon. The subsequent reduction of salinity and the potential contaminant increases in the lagoon waters may have negatively affected the lagoon phytoplankton communities in favor of the bacterial community that benefitted from the discharged nutrients. Therefore, the biomass enrichment usually observed during a flash flood event may be mainly due to the accumulation of discharged freshwaters autotrophic biomass. These hypotheses were evaluated during the same flash flood event as that investigated by Pecqueur et al (2011). Here we quantify for the first time the main flood nutrient and contaminant loadings discharged into a Mediterranean lagoon and the concomitant phytoplanktonic and bacterial $\mathrm{C}$ and $\mathrm{N}$ production measured in the lagoon surface waters during and after the flash flood event in 2008. 


\section{Material and methods}

\subsection{Study site}

Thau Lagoon is one of the largest French Mediterranean lagoons $\left(43^{\circ} 24^{\prime} \mathrm{N}-3^{\circ} 36^{\prime} \mathrm{E}\right)$ with an area of about $70 \mathrm{~km}^{2}$. It produces 15,000 tons of shellfish per year which is amongst the highest in the Mediterranean. This shallow lagoon (average depth $4 \mathrm{~m}$ ) is connected to the Mediterranean Sea through three narrow channels. Water temperature and salinity vary annually between 4$29^{\circ} \mathrm{C}$ and $28.5-40$, respectively (Collos et al 2009) and wind plays an important role in the hydrodynamics (Millet 1989).

The Thau Lagoon $290 \mathrm{~km}^{2}$ catchment area consists of karstified limestone and Miocene marls and is drained by ten intermittent rivers. The Vène River drains the largest catchment area (67 $\mathrm{km}^{2}$ ) and its functioning is affected by karstic springs during the winter, urban runoff during rainy periods and wastewater effluent during dry, sunny periods (Perrin and Tournoud 2009). Every year, rivers and aquifers bring two-thirds of the nitrogen load into the lagoon and a single flood can contribute a quarter of the annual nitrogen supply (Tournoud et al 2006). The nitrate concentrations measured in the lagoon are closely related to rainfall events (Collos et al 2009) and following such events, phytoplankton blooms (mainly constituted by diatoms) are fuelled by nitrate as the $\mathrm{N}$ source (Collos et al 1997, 2009).

\subsection{River flash flood characteristics and particulate and dissolved matter loading in Vène River station}

The river inputs from the Thau catchment to the lagoon were monitored at the outlet of the Vène (Vène River Station: $43^{\circ} \mathrm{N} 28^{\prime \prime} 10.2^{\prime \prime} 03^{\circ} \mathrm{E} \mathrm{41"14.7",} \mathrm{Fig.} \mathrm{1).} \mathrm{Rainfall} \mathrm{data} \mathrm{were} \mathrm{recorded} \mathrm{every} \mathrm{five}$ minutes from three tipping bucket rain gauges located in the Vène catchment area. The flood event was monitored at the gauging station on the Vène, a few hundred meters upstream from the outlet to Angle Creek, a shallow creek. The water level and conductivity of the river was measured continuously with in situ autonomous probes. The flood event began on November $1^{\text {st }}$, 2008 at 23:30 (local time). Water samples, henceforth referred to as flood samples, were collected from the river during the flood using an automatic sampling device located at the gauging station. Flood samples were taken every 30 min during the first $6 \mathrm{~h}$, and then every $2 \mathrm{~h}$ for two days, every $6 \mathrm{~h}$ for the following 4 days and every 3 days during the recession period up to 18 November.

Flood samples were stored in the dark and brought back to the laboratory every $6 \mathrm{~h}$. The concentrations of suspended solid materials (SSM), ash free dry mass (AFDM), nitrate $\left(\mathrm{NO}_{3}+\right.$ $\mathrm{NO}_{2}$ ), phosphate and dissolved organic carbon (DOC) were analyzed using prefiltered samples (Whatman GF/F glass-fiber filters). Suspended solids were weighed on the filters after filtering 2 L. $\mathrm{NO}_{3}$ and $\mathrm{NO}_{2}$ were analyzed on filtered samples by reduction of $\mathrm{NO}_{3}$ in a Cu-Cd column (EN ISO 13395), followed by nitrite determination (EN 26777). Phosphate from filtered samples was analyzed using the standard molybdate blue method (EN 1189). Dissolved silicate and trace element contents (referred as total dissolved trace metal concentrations) were determined using inductively-coupled plasma mass spectrometry (Q-ICPMS X series II Thermo Fisher $\circledast$ at the University of Montpellier 2 trace element laboratory (GPTR/AETE)) giving an analytical precision with a margin of error of less than $8 \%$. Samples were collected in acid-cleaned HDPE bottles. They were then filtered through $0.22 \mu \mathrm{m}$-pore size polyvinylidene difluoride (PVDF) membranes (Millipore). The filtered samples were acidified $(\mathrm{pH} 2)$ with Merck Suprapur $\mathrm{HNO}_{3}$ and stored in 
polyethylene bottles pre-cleaned with acid at $4^{\circ} \mathrm{C}$ before analysis. DOC analysis was carried out on a Shimadzu TOC-VCSH total carbon analyzer using catalytically aided platinum $680^{\circ} \mathrm{C}$ combustion, with a TOC-ASI-V auto-sampler. Samples were sparged with $2 \mathrm{M} \mathrm{HCl}$ and sparged with air (free from carbon dioxide and organic impurities) to remove all inorganic carbon prior to combustion. Samples for measuring the organic carbon concentration were collected using amber glass bottles that had previously been rinsed with nitric acidic solution (20\%) and ultrapure water grade water (Millipore Milli-Q) and then grilled $\left(500^{\circ} \mathrm{C}\right.$ overnight). The filtered samples were acidified ( $\mathrm{pH}$ 2) with Merck Suprapur $\mathrm{H}_{3} \mathrm{PO}_{4}$ and stored in pre-cleaned amber glass bottles at $4^{\circ} \mathrm{C}$ before analysis (Peltzer et al 1996, Wallace et al 2002).

The river discharge $\left(\mathrm{m}^{3} \mathrm{~s}^{-1}\right)$ was derived from water level measurements using a rating curve. The instantaneous flux of particulate and dissolved matter (mass per unit of time) was calculated from the product of the concentration in the flood samples and the river water discharge. The load of flood material (i.e. the mass of material) over a specific period was defined as the integration of instantaneous fluxes over time. Since the river discharge was monitored continuously but the concentration was only measured occasionally using samples, the flood load was estimated from the discrete sum of the products of discharge at 5 min steps using a linear interpolation of the concentration between samples as described by Salles et al (2008). The temporal distribution of loads during the event period is illustrated by the normalized cumulative plot that shows the normalized cumulative load versus the normalized cumulative volume (Deletic 1998, Bertrand-Krajewski et al 1998).

\subsection{Sampling and measurements at Thau lagoon stations}

\subsubsection{Sampling in the lagoon before, during and after the flash flood event}

The surface lagoon waters (the first $0.20 \mathrm{~m}$ depth) near the Vène outlet (Lagoon Reference Station: $43^{\circ} \mathrm{N} 27^{\prime \prime} 13^{\mathrm{met}} ; 3^{\circ} \mathrm{E} 40^{\prime \prime} 21^{\mathrm{ck}}$, see Fig. 1) were sampled at this site on October $30^{\text {th }}, 2008$ and November $12^{\text {th }}, 2008$, respectively, before and after the flash flood event, in order to assess the hydrological, chemical and biological parameters during the pre- and post-flash flood period.

During the flash flood (from November $2^{\text {nd }}$ to $6^{\text {th }}, 2008$ ), the surface waters (top $0.20 \mathrm{~m}$ ) were sampled along a horizontal gradient with fixed salinity (4-5 stations ranging from 18 to 38 , referred as Lagoon Flood Stations). The location of the sampling stations was adjusted every day after changes in the daily flood discharges and in the wind-controlled current patterns in Angle Creek (Fig. 1).

\subsubsection{Light, salinity, temperature, $\mathrm{pH}$ measurements}

At the selected sampling stations in the lagoon, the $\mathrm{pH}$, temperature and salinity were measured along the whole water column using a handheld multiparameter probe (multi350i, WTW). Two ultra-miniature depth and light intensity (PAR, Photosynthetic Available Radiation) recorders (MDS-MkV/D and MDS-MkV/L respectively, JFE Advantech Co Ltd) were fastened to the probe. The apparent coefficient of light attenuation $(\mathrm{Kd})$ was calculated by applying the model of the exponential decrease of light intensity with depth to downward light profiles (Kirk 1994). The top few centimeters of the surface waters were not included in the model of light exponential decrease because waves caused strong light variability. 


\subsubsection{Dissolved inorganic and organic nutrient measurements}

Ammonium $\left(\mathrm{NH}_{4}\right)$ concentrations were measured immediately after sampling in unfiltered samples (50mL) using a spectrophotometer (Hitachi U-3000) and the indophenol blue method (Koroleff 1983). For nitrate and nitrite $\left(\mathrm{NO}_{3}, \mathrm{NO}_{2}\right)$, phosphate $\left(\mathrm{PO}_{4}\right)$ and silicate $\left(\mathrm{Si}(\mathrm{OH})_{4}\right)$ analysis, $80 \mathrm{ml}$ of water was filtered through glass-fiber filters (Whatman GF/F, $47 \mathrm{~mm}$ ), then stored frozen $\left(-20{ }^{\circ} \mathrm{C}\right)$ until analysis using an automated colorimeter (Skalar) using standard nutrient analysis methods (Tréguer and Le Corre 1975).

Dissolved organic carbon concentration (DOC) was determined from filtered (Whatman GF/F) $30 \mathrm{ml}$ samples in duplicate, collected in pre-combusted $\left(450^{\circ} \mathrm{C}\right.$, overnight) glass tubes, sealed with a Teflon lined cap, after preservation with $36 \mu \mathrm{l} 85 \%$ phosphoric acid $\left(\mathrm{H}_{3} \mathrm{PO}_{4}\right)$. Samples were stored at ambient temperature in the dark until measurement. DOC concentration was measured using a Shimadzu TOC VCPH analyzer, using potassium phthalate calibration

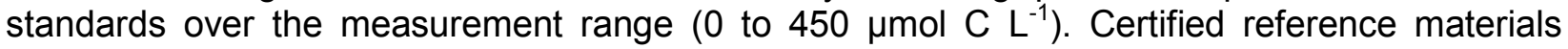
(Hansell Laboratory, University of Miami) were used to assess the performance of the instrument

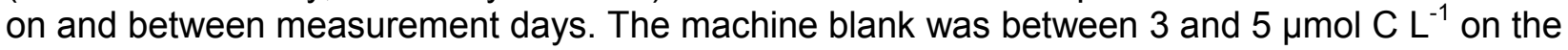
measurement days and the coefficient of variation (CV) of the measurement was always less than $2 \%$ of the mean of triplicate injections of duplicate samples.

\subsubsection{Labile dissolved trace metal concentrations from Diffusive Gradient in Thin film (DGT)}

The DGT technique (Diffusive Gradient in Thin Film) was used to extract and concentrate in situ cadmium, cobalt, chrome, copper, manganese, nickel, lead and zinc. The DGT probes consisted of a layer of polyacrylamide hydrogel backed by a layer of chelating resin. The recovered metals from DGT probes refer to the labile fraction of metals. The in situ samplers used were developed by Lancaster University (Davison \& Zhang, 1994; Zhang \& Davison, 1995) in collaboration with the UK Environment Agency. They are used in routine $\mathrm{Cd}, \mathrm{Cu}, \mathrm{Pb}, \mathrm{Ni}$ and $\mathrm{Zn}$ analyses and are referenced (ISO 17 025) by UKAS.

Triplicate DGT"s attached to samplers were immersed $1 \mathrm{~m}$ below the surface on October $22^{\text {nd }}$ and November $3^{\text {rd }}$ and $12^{\text {th }}$ at the Lagoon Reference Station (Fig. 1). During each operation, the water temperature and salinity were measured. The DGTs were recovered approximately 2 days after immersion. During recovery, the DGTs were rinsed immediately with ultra pure water, placed in clean storage boxes and kept in an ice box for return to the laboratory. The DGTs were processed under trace metal clean conditions.. The DGT resins were collected, placed in a clean, polyethylene tube and eluted (at least $24 \mathrm{~h}$ before analysis) with $1.8 \mathrm{ml}$ "Suprapur" $1 \mathrm{~mol} \mathrm{~L}$ "

${ }^{1}$ nitric acid. All of the items used were conditioned beforehand using trace element cleaning methods. The eluted samples were analyzed using ICP-MS to determine the mass of the various metallic elements accumulated in the resin.

The concentration in metal $\left(\mathrm{C}_{\mathrm{DGT}}\right)$ was calculated according to the following equation:

$\mathrm{C}_{\mathrm{DGT}}=\mathrm{M} \Delta \mathrm{g} / \mathrm{tADm}$

where

$\mathbf{M}$ is the mass of the metallic cation analyzed after the resin elution;

$\Delta \mathbf{g}$ is the diffuse gel characteristics; 
$\mathbf{t}$ is the DGT immersion time;

A is the surface of exposed gel;

Dm is the diffusion coefficient of the metal in the gel (predetermined by Lancaster Research Ltd and corrected according to the sample site temperature).

Blanks were prepared in the field as well as on each new DGT set used to control and qualify any contamination during preparation, transportation and deployment of the DGTs. Measurements were taken in triplicate to define the standard deviation for mean labile metal concentrations taking into account of the potential contamination of blanks and DGT repeatability.

\subsubsection{Microbial carbon biomass}

The bacterioplankton biomass was estimated from microbial abundances determined for the surface water of each station as described in detail by Pecqueur et al (2011). Frozen fixed samples $\left(2 \%\right.$ formaldehyde, frozen at $-196^{\circ} \mathrm{C}$ and stored at $\left.-80^{\circ} \mathrm{C}\right)$ were thawed and analyzed using a FACSCalibur flow cytometer (Becton-Dickinson, Franklin Lakes, NJ, USA) equipped with an air-cooled laser providing $15 \mathrm{~mW}$ at $488 \mathrm{~nm}$ with the standard filter set-up. For bacterial cell counts, induced fluorescence was obtained by SYBR Green I staining (S7563, Invitrogen, $2 \%$ final concentration, dark incubation at room temperature for $20 \mathrm{~min}$ ). Bacteria were enumerated using calibrated Becton-Dickinson TrucountTM beads as an internal standard. The data were analyzed using CellQuest Pro (Becton-Dickinson). The bacterial abundances were then converted into carbon biomass using a standard factor of $20 \mathrm{fg} \mathrm{C}^{-1}$ cell $^{-1}$ (Lee \& Fuhrman 1987).

The phytoplankton biomass was estimated from chlorophyll a (chl a) concentrations. Samples $(0.1 \mathrm{~L}$ to $1 \mathrm{~L}$ ) were filtered onto glass-fiber filters (Whatman GF/F, $25 \mathrm{~mm}, 0.7 \mu \mathrm{m}$ nominal pore size) frozen in liquid nitrogen and then stored at $-80^{\circ} \mathrm{C}$ until analysis. Chl a was extracted in $2 \mathrm{ml}$ of $95 \%$ methanol and then analyzed by HPLC following the method described by Zapata et al. (2000) with some modifications for the HPLC system used (Vidussi et al 2011).. Chl a concentrations were converted into carbon using a carbon:chl a ratio of 50 (Reynolds 2006), close to the average reported for surface waters the north west Mediterranean (Delgado 1992, Latasa 2005).

Protozooplankton biomass was estimated from naked ciliates and heterotrophic flagellates. Naked ciliates were counted and measured using an inverted microscope (Olympus IX70). 100 $\mathrm{ml}$ preserved samples with $6 \%$ Lugol"s iodine solution were left to settle in an Utermöhl chamber for $24 \mathrm{~h}$, then counted and classified in various size fractions as 10-15, 15-20, 20-25, 25-30 $\mu \mathrm{m}$. To calculate the biovolume of naked ciliates, the cell was considered as a sphere with the diameter of the median of each size class (i.e. 12.5, 17.5, 22.5, and $27.5 \mu \mathrm{m}$ ). Naked ciliate

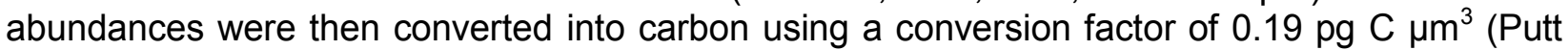
and Stoecker 1989). Heterotrophic flagellates were fixed using formaldehyde (final concentration $6 \%$ ), filtered onto $25 \mathrm{~mm}$ diameter $0.2 \mu \mathrm{m}$ pore size black Nuclepore polycarbonate membranes, stained using 4",6"-diamidino-2-phenyindole hydrochloride (final concentration $2.5 \mu \mathrm{g} \mathrm{mL}^{-1}$ ) and counted using an epifluorescent microscope (Olympus AX70). Heterotrophic flagellates were classified in two size classes of $<3$, and 3-5 $\mu \mathrm{m}$. To calculate the biovolume, each cell was considered as a sphere with a median diameter of 1.5 and $4 \mu \mathrm{m}$ for each of two size classes and

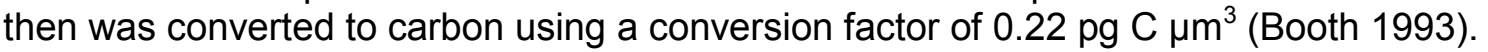




\subsubsection{Bacterial production and turnover rates}

The net bacterial production was estimated from the DNA synthesis rates measured by $\left({ }^{3} \mathrm{H}\right.$ methyl) thymidine $\left({ }^{3} \mathrm{H}-\mathrm{TdR}\right)$ incorporation (Smith \& Azam 1992). A subsample was added to a sterile polystyrene snap cap tube containing a final saturating concentration of $20 \mathrm{nM}$ of ${ }^{3} \mathrm{H}-\mathrm{TdR}$ (specific activity $53 \mathrm{Ci} \mathrm{mmol}^{-1}$, Amersham). Triplicate live samples and a control were run for each assay. The bacterial growth was measured in the dark at in situ temperature for a short incubation time (no longer than $1 \mathrm{~h}$ ). Incorporation was terminated by adding TCA (5\% final concentration) and samples were then stored for at least $2 \mathrm{~h}$ at $4^{\circ} \mathrm{C}$. After centrifugation, the precipitates were rinsed three times with 5\% TCA and then resuspended in a liquid scintillation cocktail (Ultima Gold LLT, Perkin Elmer) before the radioactivity was determined using a liquid scintillation counter (Beckman LS 6500). Radioactivity was counted by liquid scintillation and the results were expressed in $\mu \mathrm{g} \mathrm{C} \mathrm{L}^{-1} \mathrm{~h}^{-1}$ using $2 \times 10^{18}$ cells mol ${ }^{-1} \mathrm{TdR}$ (Bell 1990) and assuming

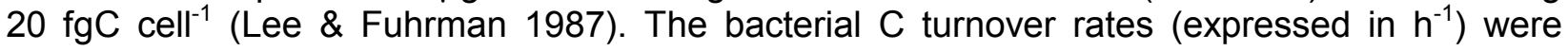
estimated as the ratio between net bacterial production and bacterial $\mathrm{C}$ biomass.

\subsubsection{Dissolved inorganic carbon and nitrogen uptake and turnover rates}

The net carbon and nitrogen uptake rates ( $\mathrm{C}$ and $\mathrm{N}$ uptake rates) were assessed in surface water samples using stable isotope tracers (Dugdale \& Wilkerson, 1986). Both ${ }^{15} \mathrm{~N}\left[\mathrm{~K}^{15} \mathrm{NO}_{3}\right.$ or $\left({ }^{15} \mathrm{NH}_{4}\right)_{2} \mathrm{SO}_{4}$ ] and sodium bicarbonate- ${ }^{13} \mathrm{C}$ solution (99 atom $\%{ }^{13} \mathrm{C}$ ) at a final concentration of 0.05 and $100 \mu \mathrm{mol} \mathrm{L} \mathrm{L}^{-1}$, respectively, were added to $500 \mathrm{ml}$ sample bottles in triplicate. All the bottles were then incubated in situ under natural light for $4 \mathrm{~h}$ around midday. At the end of incubation, the samples were filtered onto precombusted Whatman GF/F filters and stored at $80^{\circ} \mathrm{C}$ until analysis. Filter samples were dried at $60^{\circ} \mathrm{C}$ for $24 \mathrm{~h}$, pelleted and analyzed for ${ }^{13} \mathrm{C}:{ }^{12} \mathrm{C}$ and ${ }^{15} \mathrm{~N}:{ }^{14} \mathrm{~N}$ isotope ratios and particulate organic carbon and nitrogen (POC and PON, respectively) using an ANCA mass spectrometer (Europa Scientific). The net absolute nitrogen uptake rates ( $\rho \mathrm{N}$ and $\rho C$ ) were calculated using Dugdale \& Wilkerson"s equation (1986), assuming a reduced $\mathrm{N}$ regeneration (no isotope dilution) during the $4 \mathrm{~h}$ of incubation, as confirmed from the decrease of $\mathrm{NH}_{4}{ }^{+}$and $\mathrm{NO}_{3}{ }^{-}$concentrations measured at the beginning and at the end of the $6 \mathrm{~h}$ incubation. The total dissolved inorganic carbon was estimated from salinity measurements as described in Strickland \& Parsons (1968). The uptake rates were expressed in $\mu \mathrm{g} \mathrm{L}^{-1} \mathrm{~h}^{-1}$. The phytoplankton $\mathrm{C}$ turnover rates (expressed in $\mathrm{h}^{-1}$ ) were estimated as the ratio between the $\mathrm{C}$ uptake rates and the phytoplankton $\mathrm{C}$ biomass. The microbial DIN turnover rates (expressed in $\mathrm{h}^{-1}$ ) were estimated as the ratio between the DIN $\left(\mathrm{NO}_{3}+\mathrm{NH}_{4}\right)$ uptake rates and the sum of both bacterial and phytoplankton $\mathrm{N}$ biomass estimated using a typical $\mathrm{C}: \mathrm{N}$ ratio of 5 and 7, respectively (Goldman et al 1987, Fagerbakke et al 1996, Redfield et al 1963).

\section{Results}

\subsection{Characteristics of the flood event and particulate and dissolved loadings at the Vène River station}

Five different flood periods were distinguished for samples taken on November $3^{\text {rd }}, 4^{\text {th }}, 5^{\text {th }}$ and $6^{\text {th }}$, called Day 1, Day 2, Day 3, and Day 4 respectively. Period 1 was defined from 23:30 on November $1^{\text {st }}$ to 10:00 on Day 1, Period 2 from 10:00 on Day 1 to 10:00 on Day 2, Period 3 from 10:00 on Day 2 to 10:00 on Day 3, Period 4 from 10:00 on Day 3 to 10:00 on Day 4, and Period 
5 from 10:00 on Day 4 to November $17^{\text {th }}$, which was taken to be the end of the recession period. The flood was generated by a large storm followed by a series of five rain showers (Fig. 2). The water flow rate had three main peaks due to fast runoff from impermeable areas and flow from karstic springs. The first peak occurred during the first 8 hours of the flood and the second corresponded to the second rain shower on November $2^{\text {th }}$ in the afternoon. The last peak lasted from the night of November $3^{\text {rd }}$ to November $6^{\text {th }}$ and was due to the last series of rain showers combined with karstic flow (Fig. 2). After the first peak, karstic water maintained the flood flow during the intervals between peaks. Almost $45 \%$ of the total water volume was discharged during the first five days of the flood event. The river flash flood period was then defined as the first five days of the flood (from November $2^{\text {nd }}$ to $6^{\text {th }}$ or Period 1 to Period 4 ) when river flow rates were significantly higher. From November $6^{\text {th }}$ onwards, river discharge decreased slowly until November $17^{\text {th }}$. Total flood volume was $5.510^{6} \mathrm{~m}^{3}$. The total flood load, expressed in mass, is shown in Table 1 for particulate and dissolved matter and total dissolved trace metals.

The plots of normalized cumulative load (NCL) against the normalized cumulative volume (NCV) are shown in Figures $3 a$ and $3 b$ in relation with the different periods (1, 2, 3, 4 and 5). The first flush effects (i.e. substantial increase of loads during the rising of the flood event) were observed for particulate material (SSM, AFDM, particulate phosphorus). More than $40 \%$ of the total particulate material was flushed away during the first period (Fig. 3a). Dissolved copper (Cu) and lead $(\mathrm{Pb})$ were also subject to high flush effects with more than half of the $\mathrm{Cu}$ and $\mathrm{Pb}$ flood load was flushed during this initial period (Fig. 3b). Dissolved inorganic nitrogen (nitrate + nitrite), nickel $(\mathrm{Ni})$ and chrome $(\mathrm{Cr})$ were subject to a more moderate flush effect (Fig. 3a and $3 b$ ). Flushing of dissolved inorganic nitrogen, $\mathrm{Cu}, \mathrm{Pb}, \mathrm{Ni}$ and $\mathrm{Cr}$ represented cumulative loads 1647 $\mathrm{kgN}, 5.7 \mathrm{~kg}, 0.17 \mathrm{~kg}, 0.83 \mathrm{~kg}$ and $0.45 \mathrm{~kg}$, respectively, from period 1 to period 4 of the flood. In contrast, the flux of dissolved phosphorus, dissolved organic carbon (DOC) and silicate and some trace elements such as Cadmium (Cd) and Cobalt (Co) were related directly to the flow with the NCL vs NCV plots scattered along the 1:1 line (Fig. 3a and 3b).

\subsection{Characteristics of the lagoon surface waters during the study}

3.2.1. Characteristics of lagoon surface waters at the Lagoon Reference Station before and after the flash flood event

Lagoon waters sampled three days before the flash flood (on October $30^{\text {th }}$ ) at the Lagoon Reference station (Fig.1) had vertically homogeneous temperature and salinity profiles averaging $12.1^{\circ} \mathrm{C}$ and 38.4 , respectively $(n=8$, Table 2). The apparent coefficient of light attenuation $(\mathrm{Kd})$ was $0.6 \mathrm{~m}^{-1}$ before the flash flood event. During this period, the concentrations of nitrate and phosphate in the surface lagoon waters (top $0.2 \mathrm{~m}$ ) were low $\left(<20 \mu \mathrm{g} \mathrm{N} \mathrm{L}^{-1}\right)$ relative to the ammonium and silicate concentrations (Table 2).

Six days after the flash flood event (November $12^{\text {th }}$, period 5 ), the surface water at the outlet station was warmer $\left(14.8^{\circ} \mathrm{C}\right)$ and had a lower salinity (35). Nitrate and ammonium concentrations and uptake rates increased significantly in these surface waters after the flash flood event (Table 2). Similarly, the concentrations of Co, Cr, $\mathrm{Zn}$ and Ni measured in the surface waters of the Lagoon Reference Station were significantly higher during and after the flash flood event. (Table 3). Indeed Zn concentration increased by an order of magnitude to over $70 \mu \mathrm{L} \mathrm{L}^{-1}$ during and after the flash flood event. However, concentrations of silver ( $\mathrm{Ag}), \mathrm{Cd}, \mathrm{Pb}$ and $\mathrm{Cu}$ in the surface lagoon waters were not significantly different 6-8 days after the flash flood from those measured before the flash flood event (Table 3). 
After the flash flood event, the bacterial $\mathrm{C}$ biomass was always greater than phytoplankton biomass. After the flash flood event, bacterial $C$ biomass increased from 82 to $152 \mu \mathrm{g} \mathrm{C} \mathrm{L}^{-1}$ while phytoplankton biomass increased from 34 to $82 \mu \mathrm{g} \mathrm{C} \mathrm{L}^{-1} \mathrm{~h}^{-1}$ (Table 2). Primary production increased by a factor of 3 whereas bacterial production and turnover rates as well as DIN turnover did not change significantly after the flood event. Similarly high increases in $\mathrm{NH}_{4}$ and $\mathrm{NO}_{3}$ uptake rates were observed after the event whereas DIN turnover did not change significantly.

\subsubsection{Characteristics of the Lagoon Flood Stations during the flash flood event}

\subsubsection{Physical characteristics of the Lagoon Flood Stations during the flash flood event}

Vertical salinity stratification was observed in less saline waters $(<32)$, however this stratification was restricted to the upper $0.5 \mathrm{~m}$ on the last day of the flash flood event. The temperature ranged between 13 and $15^{\circ} \mathrm{C}$ and $\mathrm{pH}$ between 7.7 and 8.1 , with saline waters being warmer and more alkaline in general (data not shown) during the flood event. Light attenuation (Kd) decreased in less saline waters from $2.2 \mathrm{~m}^{-1}$ (on Day 1 and 2) to $0.4 \mathrm{~m}^{-1}$ (on Day 4) and varied between 0.2 and $0.4 \mathrm{~m}^{-1}$ at more saline stations (data not shown).

3.2.2.2. Dilution of dissolved and particulate matter in the Lagoon Flood Stations during the flash flood

In Figure 4 the linear regressions of salinity vs the chemical data are reported. During the first five days of the flash flood event, concentrations of nitrate, silicate, phosphate and ammonium were all significantly correlated negatively and linearly with increasing salinity. In Figure 5 the linear regressions of salinity vs dissolved and particulate organic carbon DOC and POC respectively) and particulate organic nitrogen (PON) are reported. Concentrations of DOC also decreased significantly with increasing salinity on Day 1 and Day 3 (Fig. 5a). However, on Day 2 and on Day 4 the DOC concentrations (mean $2237 \mu \mathrm{g} \mathrm{C} \mathrm{L}^{-1}$ ) were lower than those determined before the flood event $\left(2808 \mu \mathrm{gC} \mathrm{L}^{-1}\right)$. The concentration of particulate organic matter (POC and PON) decreased linearly with increasing salinity during the flash flood event.

The concentrations of $\mathrm{NO}_{3}+\mathrm{NO}_{2}, \mathrm{PO}_{4}$, silicate, and DOC measured from Day 1 to Day 4 were compared to the theoretical diluted values (Fig. 6). These theoretical values were estimated for each sample day from i) the nutrient flood loads estimated for each corresponding period and ii) the salinity values measured at each station (S1 to S4) assuming that nutrient concentrations measured in the most saline waters (S5) were conservative along the salinity gradient during the day in question. The concentrations of $\mathrm{NO}_{3}+\mathrm{NO}_{2}$ measured in the dilution plume were relatively close to the theoretical concentrations, although some values measured in saline waters were much lower than the theoretical values (Fig. 6a). Some differences between the theoretical diluted values and the measured values were also recorded for phosphate (Fig. 6a), DOC and silicate (Fig. 6b), with concentrations in brackish waters differing from the theoretical diluted values.

3.2.2.3. Dynamics of lagoon microbial carbon biomass compartments in the Lagoon Flood Stations during the flash flood 
In general, the highest biomass of bacterioplankton and phytoplankton were measured in the less saline surface waters (165 and $152 \mu \mathrm{g} \mathrm{C} \mathrm{L}^{-1}$, respectively) and on the first sampling day (Day 1). Bacterial $\mathrm{C}$ biomass (averaging $84 \mu \mathrm{g} \mathrm{C} \mathrm{L}^{-1}$ ) always dominated the microbial $\mathrm{C}$ biomass

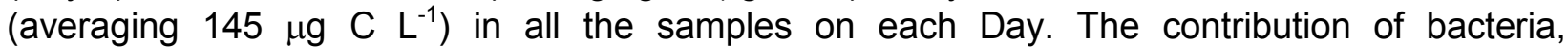
phytoplankton and protozooplankton to the total microbial C biomass averaged $59 \%( \pm 9), 36 \%$ $( \pm 9)$ and $5 \%( \pm 2)$, respectively and did not vary greatly at the sampled stations during the sampling period.

3.2.2.4. Dynamics of lagoon microbial carbon production and nitrogen uptake rates in the Lagoon Flood Stations during the flash flood

Primary production (PP) in surface waters varied slightly along the salinity gradient averaging $2.7 \mu \mathrm{g} \mathrm{L} \mathrm{L}^{-1} \mathrm{~h}^{-1}$ during the flash flood event, except on Day 4 (Fig. 7a). Interestingly, the highest PP value (4.2 $\mu \mathrm{g} \mathrm{C} \mathrm{L}^{-1} \mathrm{~h}^{-1}$ ) was measured on Day 4 in the two most saline waters whereas the lowest values were measured in less saline waters $\left(0.5 \mu \mathrm{g} \mathrm{L} \mathrm{L}^{-1} \mathrm{~h}^{-1}\right)$. Bacterial production (BP) generally decreased linearly with increasing salinity except on Day 2 (Fig. 7a) with the lowest values always reported in the most saline waters.

During the flash flood, the contribution of nitrate uptake to the total dissolved inorganic (i.e. DIN $=\mathrm{NO}_{3}+\mathrm{NH}_{4}$ ) uptake rates was highest (averaging 73\%) in the less saline waters (salinity < 25) where the highest DIN uptakes rates were generally observed (Fig. 7b.) On Day 4, the contribution of nitrate uptake averaged $60 \%$ of the total DIN uptake rates..

3.2.2.5. Lagoon bacterial and phytoplankton carbon and nitrogen biomass turnover rates in Lagoon Flood Stations during the flash flood event

In general, phytoplankton $\mathrm{C}$ biomass turnover rates (Fig. 8a) increased with increasing salinity from a minimum of $0.02 \mathrm{~h}^{-1}$ to a maximum of $0.10 \mathrm{~h}^{-1}$. The only exception was on Day 2 where high turnover rates were measured in less saline waters $\left(0.10 \mathrm{~h}^{-1}\right)$. In contrast, , bacterial biomass turnover rates generally decreased with increasing salinity (Fig. 8b) with the lowest values $\left(<0.01 \mathrm{~h}^{-1}\right)$ reported on Days 2 and 3 in the most saline waters. Similarly to bacterial biomass turnover rates, the microbial DIN turnover rates generally decreased from an average of $0.07 \mathrm{~h}^{-1}$ to $0.02 \mathrm{~h}^{-1}$ with increasing salinity (Fig. 8c).

\section{Discussion}

\subsection{Potential overall impact of dissolved matter loadings on Thau Lagoon system}

The total nitrogen and phosphorus loads measured during the present flood event represented about $8 \%$ and $3 \%$, respectively of the yearly averaged discharges estimated in Thau Lagoon (117 tons $\mathrm{N}$ and 24 tons $\mathrm{P}$ estimated from Plus et al 2006). The impact of this river flood reached $20 \%$ of the total lagoon water volume $\left(\mathrm{ca} .300 \mathrm{Mm}^{3}\right)$. This corresponds to the minimal volume of the mixed waters $\left(62 \mathrm{Mm}^{3}\right.$ ) estimated from the reduction in salinity from 38.4 to 35 observed before (30 October) and after the flash flood period (12 November) in the lagoon waters and the volume of river discharged during this event $\left(5.5 \mathrm{Mm}^{3}\right)$. Using this estimate of the mixing volume 
and the increases in nitrate and labile trace metal concentrations measured in lagoon waters during the event (Table 1), the river loads would represent $35-62 \%$ of nitrate and less than $20 \%$ of the total trace metals inputs into the lagoon during this period. Nitrate inputs from the rain and groundwaters are known to contribute to the total nitrogen loads during a flash flood event (Tournoud et al 2006). However, the apparent weak contribution of Vène River loads to the increase in the labile trace metals concentrations in the lagoon during the flood period suggests greater contributions of other sources such as runoff from urban areas. This is supported by the highest labile copper concentrations reported in surface waters close to the city of Sète during a spatial survey performed in Thau Lagoon in May 2003 without flood event (Kawami et al 2008).

\subsection{Rapid dilution of flash flood nutrients and silicate and DOC flocculation in lagoon waters}

During the first 2 days of the flood event, floodwaters were discharged into the lagoon causing a marked horizontal salinity gradient that was restricted to Angle Creek. Most of the suspended matter, dissolved copper $(\mathrm{Cu})$ and lead $(\mathrm{Pb})$ and dissolved phosphate were discharged in considerable quantities during the first 2 days (period 1) of the flash flood event. In contrast significant loads of dissolved nitrate, silicate and DOC were still observed in periods 3 and 4 (November $4^{\text {th }}-6^{\text {th }}$ ), corresponding to the second period of heavy flood discharges. In general, the concentration of nutrients $\left(\mathrm{NH}_{4}, \mathrm{NO}_{3}\right.$, Silicate, $\left.\mathrm{PO}_{4}\right)$ and particulate matter (POC and PON) measured in the surface waters of the flood plume followed a dilution gradient during the flash flood period (Fig. 4 and 5). This suggests that a rapid physical dilution of floodwaters into the lagoon saline waters mainly influenced the concentrations of these components.

Some differences between the theoretical diluted values and the measured values were recorded for phosphate concentrations with some values in brackish waters being greater than the theoretical values (Fig. 6a). It is probable that there was a source of phosphate in brackish surface waters during the flash flood period. Phosphate concentrations measured in waters close to the bottom of each station were on average $30 \%$ lower than surface concentrations (data not shown). It is, therefore, probable that the phosphate originated from phosphate desorption of particles from river in saline waters rather than from sediment efflux. A large fraction of phosphate adsorbed to particles in freshwaters desorbs from particles when discharged into seawater and this desorbed phosphate then becomes biologically available in estuaries (Froelich 1988, Némery \& Garnier 2007). These results support the occurrence of reactive transport processes inferred from the release of phosphate in seawaters observed after a Mediterranean-type flash flood event in the Bay of Banyuls-Sur-Mer (Guizien et al 2007).

On the other hand the $\mathrm{NO}_{3}+\mathrm{NO}_{2}$, DOC and silicate values measured in the plume were generally lower than the theoretical diluted values (Fig. 6a and 6b). The high nitrate uptake measured in saline waters on the last day of the flash flood period may partly explain such difference. The difference in DOC concentration between theoretical and measured values led to daily DOC losses between two and 60 times greater than the daily BP rates measured in brackish waters, hence DOC losses cannot be solely of microbial origin. Beyond transformation of refractory and labile DOC by bacterial hydrolysis for bacterial uptake and respiration reported in Mediterranean coastal waters (Northern Adriatic Sea, La Ferla et al 2002, 2006), flocculation of a large fraction of DOC discharged by river flood to seawaters seems a more probable explanation. Similarly, the silicate losses were on average 5 times greater than potential silicate assimilation by phytoplankton when estimated from the DIN uptake (assuming a stoichiometric equivalence between silicate and nitrogen uptake). Removal of dissolved organic carbon (15$20 \%$ ) and dissolved silicon (25-30\%) have been reported in temperate estuaries (Liss and 
Pointon 1973, Sholkovitz 1976) where the conversion of riverine dissolved organic matter to particulate organic matter through flocculation or precipitation, led to their settling onto sediments. These results suggest that removal of approximately $10 \%$ to $50 \%$ of flood DOC and silicate through flocculation or precipitation may occur during mixing with lagoon saline waters. This may explain the substantial reduction of DOC concentration $(20 \%)$ measured in the most saline lagoon surface waters from October $30^{\text {th }}$ (before the flood) to November $6^{\text {th }}$, inducing a potential $\mathrm{C}$ limitation of bacterial production in these waters.

\subsection{Flash flood short-time impact on bacterial communities}

Bacterial production (BP) accounted for more than $150 \%$ of primary production (PP) in brackish waters on Days 1, 2 and 4 corresponding to periods of heavy flood discharges into the lagoon. This suggests that bacterial production was mainly based on DOC from the river, despite the apparent substantial DOC losses in these waters. The intrinsic bacterial productivity (i.e. carbon turnover rates) was greater in brackish waters $\left(0.04 \pm 0.02 \mathrm{~h}^{-1}\right.$ in waters of salinity $\left.<34\right)$ than in the higher salinity lagoon waters $\left(0.010 \pm 0.006 \mathrm{~h}^{-1}\right)$ where BP accounted for only 10 to $30 \%$ of PP. Similar low ratios were reported in coastal Mediterranean waters (North and Adriatic Sea) during wintertime (La Ferla et al 2005) and these ratios are within the range of values $(2-31 \%)$ reported for coastal waters (Fouilland \& Mostajir 2010) for the PP range measured. The bacterial communities in these higher salinity waters were metabolically less active than communities in brackish waters during the flash flood, probably relying more on PP and associated DOC production than on available labile DOC stock. The reduction of the DOC concentration observed in these saline lagoon waters before and during the flash flood event, may have limited carbon production of the bacterial community. Similarly, the microbial DIN turnover rates measured in the higher salinity lagoon waters were also lower during and after the flash flood than before, despite the strong DIN enrichment in these waters. In addition to this nitrogen enrichment of saline lagoon waters during the flash flood, the concentrations of some labile heavy metals such as $\mathrm{Zn}$ also increased by $50-100 \%$ at the reference station, $6-8$ days after the flash flood event. Such contamination may have affected the metabolism of the lagoon bacterial community and subsequently reduced bacterial production rates in lagoon waters after the first day of the flash flood period. A significant reduction of approximately $20 \%$ of BP (and ca. $10 \%$ of PP) was reported, 2 hours after the addition of $\mathrm{Zn}\left(>20 \mu \mathrm{g} \mathrm{L}^{-1}\right)$ in lagoon waters in tropical coastal environments (Rochelle-Newall et al 2008). The limitation of bacterial production by heavy-metal contaminations in tropical estuarine system has also been suggested to explain the apparent low availability of DOC accumulated in waters with high salinities (Rochelle-Newall et al 2011). This suggests that the lagoon bacterial community may be rapidly inhibited by substantial $\mathrm{Zn}$ contamination. This may also explain the low microbial nitrogen turnover rates measured in saline lagoon waters despite significant nitrogen enrichments over the flash flood period.

Although increases of bacterial biomass and production were observed in brackish waters during the flash flood period, this event seems to have affected bacterial specific productivity (i.e. C turnover rates) of the lagoon community. The potential loss of bioavailable DOC via flocculation, together with contaminant discharges led to the reduction of local lagoon bacterial productivity recorded over a short time scale (i.e. within two weeks). This contrasts with previous studies performed in estuarine systems where Adriatic seawaters influenced by river discharges were characterized by high bacterial activity (La Ferla et al 2006) and freshwater DOC appeared to be of higher bioavailability to seawater bacterial communities in Randers Fjords and Scheldt estuary (Rochelle-Newall et al 2004, Bonilla Findji et al 2009). The episodic vs permanent nature 
of the freshwater discharges into the marine systems may have differently influenced the fate of the freshwater DOC and may explain these contrasted observations.

\subsection{Flash flood enhanced local lagoon primary production}

Despite of the significant discharge of phytoplankton biomass from the Vène River clearly observed on Days 1 and 3 of the flash flood period, the phytoplankton $C$ turnover was generally much higher in saline lagoon waters than in brackish waters. The osmotic shock of river phytoplanktonic communities transported into saline lagoon waters as well as that of lagoon communities mixed with river waters may reduce their fitness and may also explain the differences in specific productivity (i.e. C turnover rates) observed in surface waters along the salinity gradient. In addition, light penetration was considerably reduced in the lagoon waters mixed with floodwaters, especially during the first days of the flash flood period, owing to the large discharge of particles. Therefore, the increase in turbidity in brackish waters may also explain the reduction of phytoplankton $\mathrm{C}$ turnover rates in such waters. This decrease in specific productivity may be related to the phytoplanktonic species (Dinophycae and Prasinophycae groups) negatively affected by the flood waters (Pecqueur et al 2011). However, species from Bacillariophycae groups appeared to be resistant or carried by the river flood waters (Pecqueur et al 2011). This shift in phytoplanktonic diversity and associated production cannot be explained by the substantial discharge of $\mathrm{Zn}$ because such metallic contamination usually favors dinoflagellates to the detriment of diatoms (Rochelle-Newall et al 2008 and references therein).

Six days after the beginning of the flash flood, despite strong inputs of metal contaminants, DIN enrichments led to a substantial increase in phytoplankton $C$ production and associated DIN uptake rates (phytoplankton contributed over $60 \%$ of the total microbial DIN uptake, Trottet et al 2011) measured in saline lagoon waters. From the DIN uptake rates measured after the flash flood event (12 November) the increase in DIN concentrations owing to the river floods may be consumed within a week if there are no other $\mathrm{N}$ inputs into the lagoon and the microbial activity remains constant in surface waters. Despite the significant increase in PP, relatively low accumulations of phytoplankton carbon biomass, particulate organic carbon and nitrogen (POC and PON, respectively) were observed after the flash flood event (November $12^{\text {th }}$ ). The increase in POC and PON concentrations measured before and after the flash flood period (Table 2) combined with the estimate of the mixing volume $\left(62 \mathrm{Mm}^{3}\right)$, allows the calculation of POC and PON production during this 2-week period (respectively 6 tons of $C$ and 0.9 tons of $N$ ). Such particulate matter production represented less than $10 \%$ of the bacterial and phytoplankton $\mathrm{C}$ and $\mathrm{N}$ production estimated during this period ( 91 tons of $\mathrm{C}$ and 17 tons of $\mathrm{N}$ ) and less than $1 \%$ of the averaged yearly primary production in Thau Lagoon estimated at ca. 3600 tons of $\mathrm{N}$ by Chapelle et al (2000) and Plus et al (2006). The difference between PON production and primary and bacterial $\mathrm{N}$ production corresponds to a loss rate of $18 \mathrm{mg} \mathrm{N} \mathrm{m}^{-3} \mathrm{~d}^{-1}$ and is within the range of the averaged oyster consumption rates, estimated between 5 to $22 \mathrm{mg} \mathrm{N} \mathrm{m}^{-3} \mathrm{~d}^{-1}$ by Bacher et al $(1995,1997)$. This suggests that most of the locally produced planktonic production during the flood period may be rapidly filtered by larger organisms (oyster, mussels) contributing to about $13 \%$ of the annual exploited production (700 tons $C$ year $^{-1}$ ) in the whole Thau Lagoon (Troussellier \& Deslous-Paoli 2001). A fraction of the planktonic production may have been also exported through sedimentation, explaining the discrepancy between POC and PON production and microbial production as well.

The direct consequence of flash floods on local primary production is of particular importance to coastal lagoon systems of which there are more than 100 in the Mediterranean (Pérez-Rufaza et al. 2011). Moreover, these ecosystems occupy $13 \%$ of world"s coastlines therefore any process 
that affects microbial communities and the subsequent transfer of carbon and nitrogen up the food chain need to be taken into account. Our results show that an episodic perturbation such as a 5 day flash flood may directly impact the local microbial community and ultimately the exploited production. We also propose that the impact of these short term disturbances cannot be ignored in these systems which provide habitats for many species also well providing essential goods and services for humans.

\section{Conclusion}

This study highlighted the impact of a river flash flood, considered as a whole, on short-term microbial production and the potential consequences on a Mediterranean Lagoon. Despite the heavy discharge of most of the particulate and dissolved compounds from the Vène River within the 2 days of the flash flood, a stronger contribution of other sources such as runoffs might explain the drastic increase in labile trace metals reported in the surface lagoon waters during this event. Removal of a large fraction of freshwater DOC through flocculation may have occurred during mixing with lagoon saline waters, resulting in lower concentrations than expected. Therefore, the flash flood may have caused a $\mathrm{C}$ limitation of saline lagoon bacterial productivity mainly owing to reduced DOC availability. Initially, phytoplankton productivity in surface brackish waters seemed negatively affected by the flash flood but the subsequent DIN enrichments in saline lagoon waters was ultimately beneficial for the production of the most resilient phytoplankton community such as diatoms. These conclusions did not support the initial hypothesis that the flash flood benefitted the bacterial community over the phytoplankton community as was from biomass dynamics alone. Moreover, our results suggest that most of the enhanced bacterial and primary production resulting from the flash flood event may have benefited to exploited oysters or mussels in the lagoon and or exported through sedimentation.

\section{Acknowledgments}

We thank Michel Cantou and C. leboulanger for his assistance in the field, Louise Oriol for processing the nutrient analyses and $\mathrm{P}$. Raimbault (MIO) for performing the stable isotopes analyses. This study was part of the project "Impact des eaux de crue sur le réseau microbien de la lagune de Thau (RESTHAU)" funded by the "ECosphère Continentale et Côtière" (EC2CO) French National Program and coordinated by E. Fouilland. A. Trottet received a post-doctoral fellowship from the University of Montpellier II. D. Pecqueur received a national fellowship provided by the French Ministry of Education and Research. The authors also thank the two reviewers for their constructive comments on the manuscript.

\section{References}

Bacher, C., Bioteau, H., Chapelle, A., 1995. Modelling the impact of a cultivated oyster population on the nitrogen dynamics: the Thau Lagoon case (France). Ophelia, 42, 29-54. 
Bacher, C., Millet, B., Vaquer, A., 1997. Modelling the impact of cultivated filter-feeders on phytoplanktonic biomass of the Thau Lagoon (France). Compte Rendu de I"Académie des Sciences de Paris, Lifes Sciences, 320, 73-81.

Bertrand-Krajewski, J.-L., Chebbo, G., Saget, A., 1998. Distribution of pollutant mass vs volume in stormwater discharges and the first flush phenomenon. Water Research, 32, 2341-2356.

Bonilla-Findji, O., Rochelle-Newall, E., Weinbauer, M.G., Pizay, M.-D., Kerros, M.-E., Gattuso, J.-P., 2009. Effect of seawater-freshwater cross-transplantations on viral dynamics and bacterial diversity and production. Aquatic Microbial Ecology, 54, 1-11.

Booth, B.C., 1993. Estimating cell concentration and biomass of autotrophic plankton using microscopy, In P. F. Kemp, B. F. Sherr, E. B. Sherr, and J. J. Cole [eds.], Handbook

of methods in aquatic microbial ecology. Lewis Publishers, Boca Raton, FL, pp. 199-205.

Cherifi, O., Loudiki, M., 1999. Flood transport of dissolved and suspended matter in the El Abid river basin (Morocco). Hydrobiologia, 410, 287-294.

Chapelle, A., Menesguen, M., Deslous-Paoli, J.M., Souchu, P., Mazouni, N., Vaquer, A., Millet, B., 2000. Modelling nitrogen, primary production and oxygen in a Mediterranean lagoon. Impact of oysters farming and inputs from the watershed. Ecological Modelling, 127, 161-181.

Chu, Y., Salles, C., Cernesson, F., Perrin, J. L., Tournoud, M. G., 2008. Nutrient load modelling during floods in intermittent rivers: An operational approach. Environmental Modelling \& Software, 23, 768-781.

Chu, Y., Salles, C., Tournoud, M.-G., Got, P., Troussellier, M., Rodier, C., Caro, A., 2011. Faecal bacterial loads during flood events in Northwestern Mediterranean coastal rivers. Journal of Hydrolology. 405, 501-511.

Collos, Y., Vaquer ,A., Bibent, B., Slawyk, G., Garcia, N., Souchu, P., 1997. Variability in nitrate uptake kinetics of phytoplankton communities in a Mediterranean coastal lagoon. Estuarine Coastal and Shelf Science, 44, 369-375.

Collos, Y., Bec, B., Jauzein, C., Abadie, E., Laugier ,T., Lautier, J., Pastoureaud, A., Souchu P., Vaquer, A., 2009. Oligotrophication and emergence of picocyanobacteria and a toxic dinoflagellate in Thau lagoon, southern France. Journal of Sea Research, 61, 68-75.

Davison, W., Zhang, H., 1994. In situ speciation measurements of trace components in natural waters using thin-film gels. Nature, $367,546-548$.

Deletic, A., 1998. The First Flush Load of Urban Surface Runoff. Water Research, 32, 24622470.

Delgado, M., Latasa, M., Estrada M., 1992. Variability in the sized-fractionated distribution of the phytoplankton across the Catalan front of the North-West Mediterranean. Journal of Plankton Research, 14, 753-771.

Dugdale, R.C., Wilkerson, F.P., 1986. The use of ${ }^{15} \mathrm{~N}$ to measure nitrogen uptake in eutrophic oceans; experimental considerations. Limnology and Oceanography, 31, 673-689. 
Gouze, E., Raimbault, P., Garcia, N., Bernard, G., Picon, P., 2008. Nutrient and suspended matter discharge by tributaries into the Berre Lagoon (France): The contribution of flood events to the matter budget. Comptes Rendus Geosciences, 340, 233-244.

Guizien, K., Charles, F., Lantoine, F., Naudin, J.-J., 2007. Nearshore dynamics of nutrients and chlorophyll during Mediterranean-type flash-floods. Aquatic Living Resources, 20, 3-14.

Fagerbakke, K.M., Heldal, M., Norland, S., 1996. Content of carbon, nitrogen, oxygen, sulfur and phosphorus in native aquatic and cultured bacteria. Aquatic Microbial Ecology, 10, 15-27.

Fouilland, E., Mostajir, B., 2010. Revisited phytoplanktonic carbon dependency of heterotrophic bacteria in freshwaters, transitional, coastal and oceanic waters. FEMS Microbiology Ecology, 73, 419-429.

Froelich, P.N., 1988. Kinetic control of dissolved phosphate in natural rivers and estuaries: A primer on the phosphate buffer mechanism. Limnology and Oceanography, 33, 649-668.

Goldman, J.C., Caron, D.A., Dennett, M.R., 1987. Regulation of gross efficiency and ammonium regeneration in bacteria by substrate C:N ratio. Limnology and Oceanography, 32:1239-1252.

Harzallah, A., Chapelle, A., 2002. Contribution of climate variability to occurrences of anoxic crises 'malaigues' in the Thau lagoon (southern France). Oceanologica Acta, 25, 79-86.

Kawami, S.K., Seidel, J.-L., Elbaz-Poulichet, F., Achterberg, E.P., 2008. Trace-metal biogeochemistry in the Mediterranean Thau Lagoon, a shellfish farming area. Journal of Coastal Research, 24, 194-202.

Kirk, J.T.O., 1994. Light and Photosynthesis in Aquatic Ecosystems, Cambridge University Press, New York, 509 pp.

Koroleff, F., 1983. Determination of ammonia. In : Grasshoff, K., Ehrhardt, M., Kremling, F., (Eds.), Methods of Seawater Analysis (2nd ed.), Verlag Chemie, Weinheim, pp. 150-157.

La Ferla, R., Azzaro, M, Zaccone, R., Caruso, G., 2002. Microbial respiratory and ectoenzymatic activities in the Northern Adriatic Sea (Mediterranean Sea). Chemistry and Ecology, 18, 75-84.

La Ferla, R., Azzaro, F., Azzaro, M., Caruso, G., Decembrini, F., Leornardi, M., Maimone, G., Monticelli, L.S., Raffa, F., Santinelli, C., Zacoone, R., Ribera d"Alcalà, M., 2005. Microbial contribution to carbon biogeochemistry in the Central Mediterranean Sea: Variability of activities and biomass. Journal of Marine Systems, 57, 146-166.

La Ferla, R., Azzaro, M., Maimone, G., 2006. Microbial respiration and trophic regimes in the Northern Adriatic Sea. Estuarine, Coastal and Shelf Science, 69, 196-204.

Latasa, M., Moràn, X.A., Scharek, R., Estrada, M., 2005. Estimating the carbon flux through main phytoplankton groups in the northwestern Mediterranean. Limnology and Oceanography, 50, 1447-1458.

Lee, S., Fuhrman, J.A., 1987. Relationships between biovolume and biomass of naturally derived marine bacterioplankton. Applied Environnemental Microbiolology, 53, 1298-1303.

Liss, P.S., Pointon, M.J., 1973. Removal of dissolved boron and silicon during estuarine mixing 
of sea and river waters. Geochimica Cosmochimica Acta, 37, 1493-1498.

Millet, B., 1989. Hydrodynamic motions in the bassin de Thau. Ecological corroboration of a numerical model of circulation. Oceanologica Acta, 12, 37-46.

Monna, F., Ben Othman, D., Luck, J.M., 1995. Pb isotopes and $\mathrm{Pb}, \mathrm{Zn}$ and $\mathrm{Cd}$ concentrations in the rivers feeding a coastal pond (Thau, southern France): contraints on the origin(s) and flux(es) of metals. Science of Total Environnement, 166, 19-34.

Némery, J., Garnier, J., 2007. Typical features of particulate phosphorus in the Seine estuary (France). Hydrobiologia, 588, 271-290.

Pecqueur, D., Vidussi, F., Fouilland, E., Le Floc"h, E., Mas, S., Roques, C., Salles, C., Tournoud, M.-G., Mostajir, B., 2011. Dynamics of microbial planktonic food web components during a river flash flood in a Mediterranean coastal lagoon. Hydrobiologia, 673, 13-27.

Peltzer, E. T., Fryb, B., Doering, P., McKennac, J., Norrmand, B., Zweifeld, U., 1996. A comparison of methods for the measurement of dissolved organic carbon in natural waters. Marine Chemistry, 54, 85-96.

Pérez-Rufaza, A., Marcos C., Pérez-Rufaza, I.M., 2011. Mediterranean coastal lagoons in an ecosystem and aquatic resources management context. Physics and Chemistry of the Earth, 36, 160-166.

Perrin, J.L., Tournoud, M.G., 2009. Hydrological processes controlling flow generation in a small Mediterranean catchment under karstic influence. Hydrological Sciences Journal, 54, 11251140.

Plus, M., La Jeunesse, I., Bouraoui, F., Zaldivar, J.M., Chapelle, A., Lazure, P., 2006. Modelling water discharges and nitrogen inputs into a Mediterranean lagoon: Impact on the primary production. Ecological Modelling, 193, 69-89.

Putt, M., Stoecker, D.K., 1989. An experimentally determined carbon : volume ratio for marine „oligotrichous" ciliates from estuarine and coastal waters. Limnolology and Oceanography, 34, 1097-1103.

Redfield, J.L, Ketchum, B.H, Rickards, F.A., 1963. The infuence of organisms on the composition of seawater. In: Hill, M.N. (Ed) The sea. John Wiley \& Sons, New York, pp. 26-77.

Reynolds, C.S., 2006. Ecology of Phytoplankton. Cambridge University Press, Cambridge, 535 pp.

Rochelle-Newall, E.J., Pizay, M.D., Middelburg, J.J., Boschker, H.T.S., Gattuso, J.-P., 2004. Degradation of riverine dissolved organic matter by seawater bacteria. Aquatic Microbial Ecology, 37, 9-22.

Rochelle-Newall, E.J., Delesalle, B., Mari, X., Rouchon, C., Torréton, J.-P., Pringault, O., 2008. Zinc induces shifts in microbial carbon flux in tropical coastal environments. Aquatic Microbial Ecology, 52, 57-68.

Rochelle-Newall, E.J., Chu, V.T., Pringault, O., Amouroux, D., Arfi, R., Bettarel, Y., Bouvier, T., Bouvier, C., Got, P., Nguyen, T.M.H., Mari, X., Navarro, P., Duong, T.N., Cao, T.T.T., Pham, T.T., Ouillon, S., Torréton, J.-P. 2011. Phytoplankton distribution and productivity in a highly 
turbid, tropical costal system (Bach Dang Estuary, Vietnam). Marine Pollution Bulletin, 62, 23172329.

Salles, C., Tournoud, M.-G. , Chu, Y., 2008. Estimating nutrient and sediment flood loads in a small Mediterranean river. Hydrological Processes, 22, 242-253.

Sholkovitz, E.R., 1976 Flocculation of dissolved organic and inorganic matter during the mixing of river water and seawater. Geochimica Cosmochimica Acta, 40, 831-845.

Smith, D.C., Azam, F., 1992. A simple economical method for measuring bacterial protein synthesis rates in seawater using ${ }^{3} \mathrm{H}$-leucine. Marine Microbial Food Webs, 6, 107-114.

Strickland, J.D.H., Parsons, T.R., 1968. A practical handbook of seawater analysis. Fisheries Research Board of Canada, 167, 71-75

Tournoud ,M.G., Payraudeau, S., Cernesson, F., Salles, C., 2006. Origins and quantification of nitrogen inputs into a coastal lagoon: Application to the Thau lagoon (France). Ecological Modelling, 193, 9-33.

Tréguer, P., Le Corre, P., 1975. Handbook of seawater nutrient analyses. Autoanalyser II Technicon user guide (2nd ed.), Université de Bretagne Occidentale, Laboratoire de Chimie marine, Brest, France, pp. 1-110.

Trottet, A., Fouilland, E., Leboulanger, C., Lanouguère, E., Bouvy, M., 2011. Use of Inhibitors for Coastal Bacteria and Phytoplankton: Application to Nitrogen Uptake Rates. Estuarine Coastal and Shelf Science, 93, 151-159.

Troussellier, M., Deslous-Paoli, J.M., 2001. La lagune de Thau: un site atelier pour l"acquisition, l'intégration et la valorisation des connaissances. Océanis, 27, 257-289.

Velasco, J., Lloret, J., Millan, A., Marin, A., Barahona, M.J., Abellan, P., Sanchez-Fernandez, D., 2006. Nutrient and particulate inputs into the Mar Menor Lagoon (SE Spain) from an intensive agricultural watershed. Water, Air, and Soil Pollution, 176, 37-56.

Vidussi, F., Mostajir, B., Fouilland, E., Le Floc'h, E., Nouguier, J., Roques, C., Got, P., ThibaultBotha, D., Bouvier, T., Troussellier, M., 2011. Effects of experimental warming and increased ultraviolet-B radiation on the Mediterranean plankton food web. Limnolology and Oceanography, $56,206-218$

Wallace, B., Purcell, M., Furlong, J., 2002. Total organic carbon analysis as a precursor to disinfection byproducts in potable water: Oxidation technique considerations Journal of Environmental Monitoring, 4, 35-42

Zapata M., Rodríguez, F., Garrido, J.L., 2000. Separation of chlorophylls and carotenoids from marine phytoplankton: a new HPLC method using a reversed phase C8 column and pyridinecontaining mobile phases. Marine Ecology Progress Series, 195, 29-45.

Zhang, H., Davison, W., 1995. Performance characteristics of diffusion gradients in thin films for the in situ measurement of trace metals in aqueous solution. Analytical Chemistry, 67, 33913400 . 


\section{Figure captions}

Fig. 1. Locations of the Lagoon Flood stations (from S1 to S5) in the Angle Creek (Thau Lagoon, France) along the fixed surface salinity gradient (set between 18.8 and 37) and investigated on November the $3^{\text {rd }}$ (Day 1 in closed circles), the $4^{\text {th }}$ (Day 2 in closed diamonds), the $5^{\text {th }}$ (Day 3 in open triangles) and the $6^{\text {th }}$ (Day 4 in closed squares) during the flash flood period. The Lagoon Reference Station sampled before and after the flood event respectively on the $30^{\text {th }}$ of October and the $12^{\text {th }}$ of November is represented by a star. The Vène River station sampled during the flood event is represented by a cross.

Fig. 2. Rainfall and water flow rates measured at the Vène River Station (Thau Basin, France) during the flood event, from the $1^{\text {st }}$ to the $17^{\text {th }}$ of November 2008.

Fig. 3. Normalized cumulative load versus normalized cumulative volume for a) particulate materials (SSM, AFDM, Particulate Phosphorus) and dissolved elements (Phosphate, Nitrates + nitrites, silicate and dissolved organic carbon: $\mathrm{DOC})$, and b) trace elements ( $\mathrm{Cd}, \mathrm{Pb}, \mathrm{Cu}, \mathrm{Co}, \mathrm{Cr}$ and $\mathrm{Ni}$ ) measured at the Vène River Station during the flood period from the $2^{\text {nd }}$ to the $17^{\text {th }}$ of November 2008.

Fig. 4. Concentrations of ammonia (a), nitrate (b), silicate (c), and phosphate (c) during the flash flood period in the Lagoon Flood Stations. The distribution of values along the salinity gradient was tested for each sample day using a linear regression $\left(R^{2}, p\right.$-value). Significance level was set at $p<0.05$. The concentrations measured before the flash flood (October the $30^{\text {th }}$ ) in the surface waters of the Lagoon Reference Station (See Table 2) are shown by the horizontal dashed lines.

Fig. 5. Concentrations of dissolved organic carbon DOC (a), particulate organic carbon POC (b), and particulate organic nitrogen PON (c) during the flash flood period in the Lagoon Flood Stations. The distribution of values along the salinity gradient was tested for each sample day using a linear regression $\left(\mathrm{R}^{2}, p\right.$-value). Significance level was set at $p<0.05$. The concentrations measured before the flash flood (October the $30^{\text {th }}$ ) in the surface waters of the Lagoon Reference Station (See Table 2) are shown by the horizontal dashed lines.

Fig. 6. Ratio between observed and theoretical concentrations of a) phosphate and $\mathrm{NO}_{3}+\mathrm{NO}_{2}$ and $\mathrm{b}$ ) dissolved organic carbon (DOC) and silicate, estimated from measurements performed in the Vène River and in surface waters in the Lagoon Flood Stations along the fixed salinity gradient. Equality between the observed and the theoretical values (i.e. Ratio $=1$ ) is shown by the horizontal dashed lines.

Fig. 7. Rates of a) phytoplankton (PP) and bacterial $C(B P)$ production and b) microbial nitrate and ammonia uptake during the flash flood period in the Lagoon Flood Stations The rates measured before the flash flood (October the $30^{\text {th }}$ ) in the surface waters of the Lagoon Reference Station (see Table 2) are shown by the horizontal dashed lines (in bold for phytoplankton $\mathrm{C}$ production and Nitrate uptake rate).

Fig. 8. Rates of a) phytoplankton $C$ turnover, b) bacteria $C$ turnover and c) microbial DIN $\left(\mathrm{NO}_{3}+\mathrm{NH}_{4}\right)$ turnover during the flash flood period in the Lagoon Flood Stations. The rates measured before the flash flood (October the $30^{\text {th }}$ ) in the surface waters of the Lagoon Reference Station (see Table 2) are indicated by the stars. 
Table 1 : Total flood load (mass) for particulate, dissolved and trace elements discharged during the entire flood event at the Vène River Station. Load uncertainties (in brackets) were estimated from the difference between load calculations based on interpolation and those based on averaged concentrations

\begin{tabular}{lc}
\hline Volume $\left(\mathrm{Mm}^{3}\right)$ & 5.5 \\
AFDM (Tons) & $433(71)$ \\
$\mathrm{VSM}(\mathrm{Tons})$ & $60(17)$ \\
Total N $(\mathrm{kgN})$ & $8939(1500)$ \\
Total $\mathrm{P}(\mathrm{kgP})$ & $684(100)$ \\
\hline Silicate & $26373(700)$ \\
$\mathrm{NO}_{3}+\mathrm{NO}_{2}(\mathrm{kgN})$ & $3108(500)$ \\
$\mathrm{PO}_{4}(\mathrm{kgP})$ & $383(50)$ \\
$\mathrm{DOC}(\mathrm{kg})$ & $31364(1000)$ \\
\hline $\mathrm{Cd}(\mathrm{kg})$ & $0.043(0.001)$ \\
$\mathrm{Pb}(\mathrm{kg})$ & $0.217(0.020)$ \\
$\mathrm{Cu}(\mathrm{kg})$ & $0.007(0.0005)$ \\
$\mathrm{Co}(\mathrm{kg})$ & $0.270(0.030)$ \\
$\mathrm{Cr}(\mathrm{kg})$ & $0.754(0.020)$ \\
$\mathrm{Ni}(\mathrm{kg})$ & $1.4(0.2)$ \\
\hline
\end{tabular}


Table 2. Physical, chemical and biological variables (mean and standard deviation when available) measured in the surface waters (top $0.2 \mathrm{~m}$ ) at the Lagoon Reference Station before and after the flash flood event. nd: no data

\begin{tabular}{|c|c|c|}
\hline Measured variables & October $30^{\mathrm{B}}$ & November $12^{\mathrm{t}}$ \\
\hline Temperature $\left({ }^{\circ} \mathrm{C}\right)$ & $12,1 \quad(0.1)$ & 14.8 \\
\hline Salinity & $38.4(0.1)$ & 35.0 \\
\hline $\mathrm{NO}_{3}\left(\mu \mathrm{g} \mathrm{N} \mathrm{L}^{-1}\right)$ & 1.4 & 81.8 \\
\hline $\mathrm{NH}_{4}\left(\mu \mathrm{N} \mathrm{L} \mathrm{L}^{-1}\right)$ & $21.01 \quad(0.01)$ & $61.7(0.8)$ \\
\hline Silicate $\left(\mu \mathrm{g} \mathrm{Si} \mathrm{L}^{-1}\right)$ & 439 & nd \\
\hline Phosphate $\left(\mu \mathrm{P} \mathrm{L}^{-1}\right)$ & 14 & nd \\
\hline $\operatorname{DOC}\left(\mu \mathrm{g} \mathrm{CL}^{-1}\right)$ & $2808(16)$ & nd \\
\hline $\operatorname{POC}\left(\mu \mathrm{C} \mathrm{L}^{-1}\right)$ & $470 \quad(44)$ & $567(40)$ \\
\hline PON $\left(\mu g \mathrm{~N} \mathrm{~L}^{-1}\right)$ & $165(10)$ & $179(16)$ \\
\hline Bacterioplankton biomass ( $\mu \mathrm{g} \mathrm{C} \mathrm{L}^{-1}$ ) & 82 & 152 \\
\hline Phytolankton biomass ( $\mu \mathrm{g} \mathrm{C} \mathrm{L}^{-1}$ ) & 34 & 82 \\
\hline Protozoan biomass $\left(\mu \mathrm{g} \mathrm{C} \mathrm{L}^{-1}\right)$ & 37 & nd \\
\hline $\mathrm{NH}_{4}$ uptake rates $\left(\mu \mathrm{N} \mathrm{L}^{-1} \mathrm{~h}^{-1}\right)$ & $0.51 \quad(0.02)$ & $0.88(0.06)$ \\
\hline NO, uptake rates $\left(\mu \mathrm{g} \mathrm{N} \mathrm{L}^{-1} \mathrm{~h}^{-1}\right)$ & $0.007(0.001)$ & $0.27(0.06)$ \\
\hline $\operatorname{PP}\left(\mu g \mathrm{CL}^{-1} \mathrm{~h}^{-1}\right)$ & $2.64 \quad(0.53)$ & $7.01 \quad(0.17)$ \\
\hline $\mathrm{BP}\left(\mu \mathrm{g} \mathrm{C} \mathrm{L} \mathrm{L}^{-1} \mathrm{~h}^{-1}\right)$ & $1.07 \quad(0.06)$ & $1.45(0.20)$ \\
\hline Phytoplankton $\mathrm{C}$ tumover $\left(\mathrm{h}^{-1}\right)$ & 0,078 & 0,085 \\
\hline Bacterial $\mathrm{C}$ turnover $\left(\mathrm{h}^{-1}\right)$ & 0.013 & 0.010 \\
\hline Microbial DIN $\left(\mathrm{NO}_{3}+\mathrm{NH}_{4}\right)$ turnover $\left(\mathrm{h}^{-1}\right)$ & 0.024 & 0,027 \\
\hline
\end{tabular}


Table 3. Concentration (mean and standard deviation when available) of labile trace metals (ng L-1) measured before, during and after the flash flood event at the Lagoon Reference Station using DGT (Diffusive Gradient in Thin film).

\begin{tabular}{clccccccc}
\hline Sampling dates & $\mathrm{Ag}$ & $\mathrm{Cd}$ & $\mathrm{Co}$ & $\mathrm{Cr}$ & $\mathrm{Pb}$ & $\mathrm{Zn}$ & $\mathrm{Ni}$ \\
\hline October $22^{\text {th }}-24^{\text {th }}$ & 2.6 & $12.0(3.0)$ & $42.0(3.2)$ & $448.6(36.8)$ & 170.9 & 5786.7 & $275.0(49.3)$ & 727.2 \\
November $3^{\text {rd }}-5^{\text {th }}$ & $2.9(0.8)$ & $23.1(4.0)$ & $100.3(18.7)$ & $883.5(254.1)$ & 753.0 & 32791.4 & $467.6(87.4)$ & $1308.1(276.2)$ \\
November $12^{\text {th }}-14^{\text {th }}$ & $3.8(1.0)$ & $20.7(6.8)$ & $68.5(2.6)$ & $665.5(64.8)$ & 46.3 & 70616.8 & $387.8(9.5)$ & $792.1(53.5)$ \\
\hline
\end{tabular}




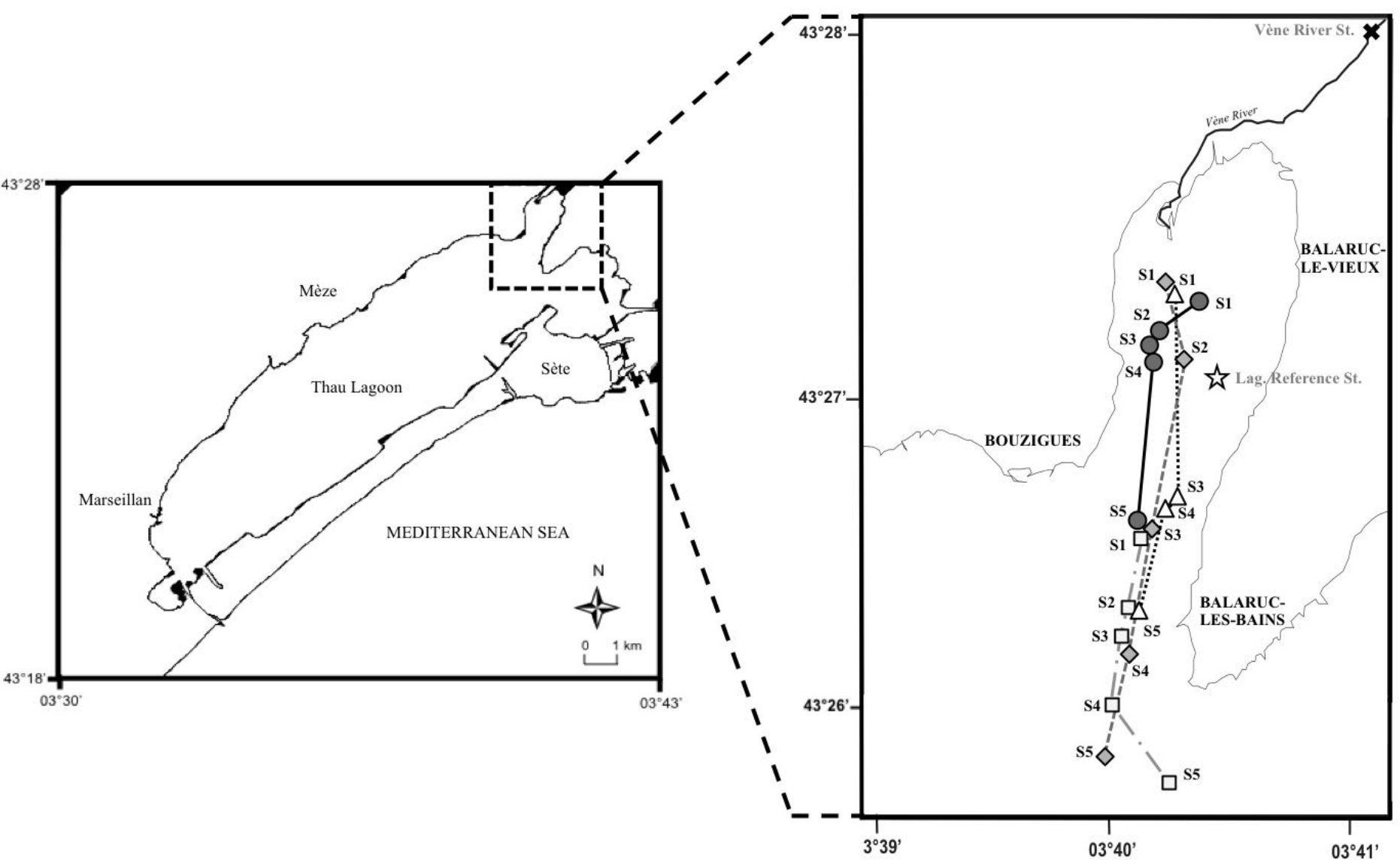

Figure 1 
Rainfall (mm)

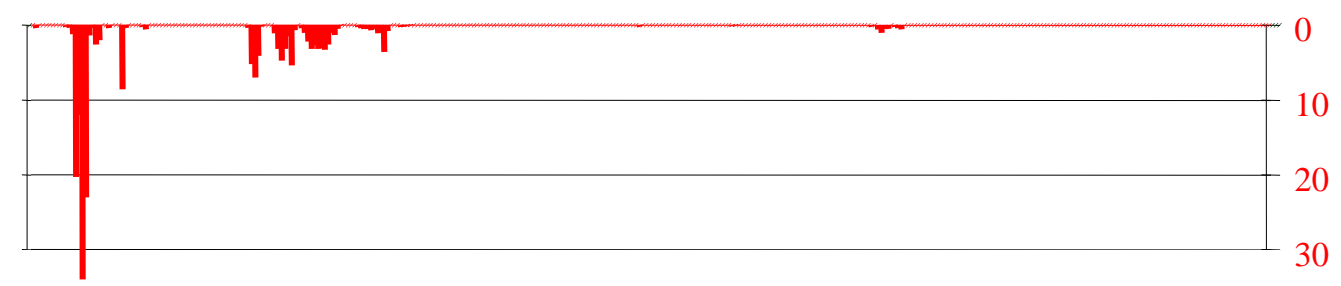

Flash flood period

Lagoon sample Day 1 Day 2 Day 3Day 4
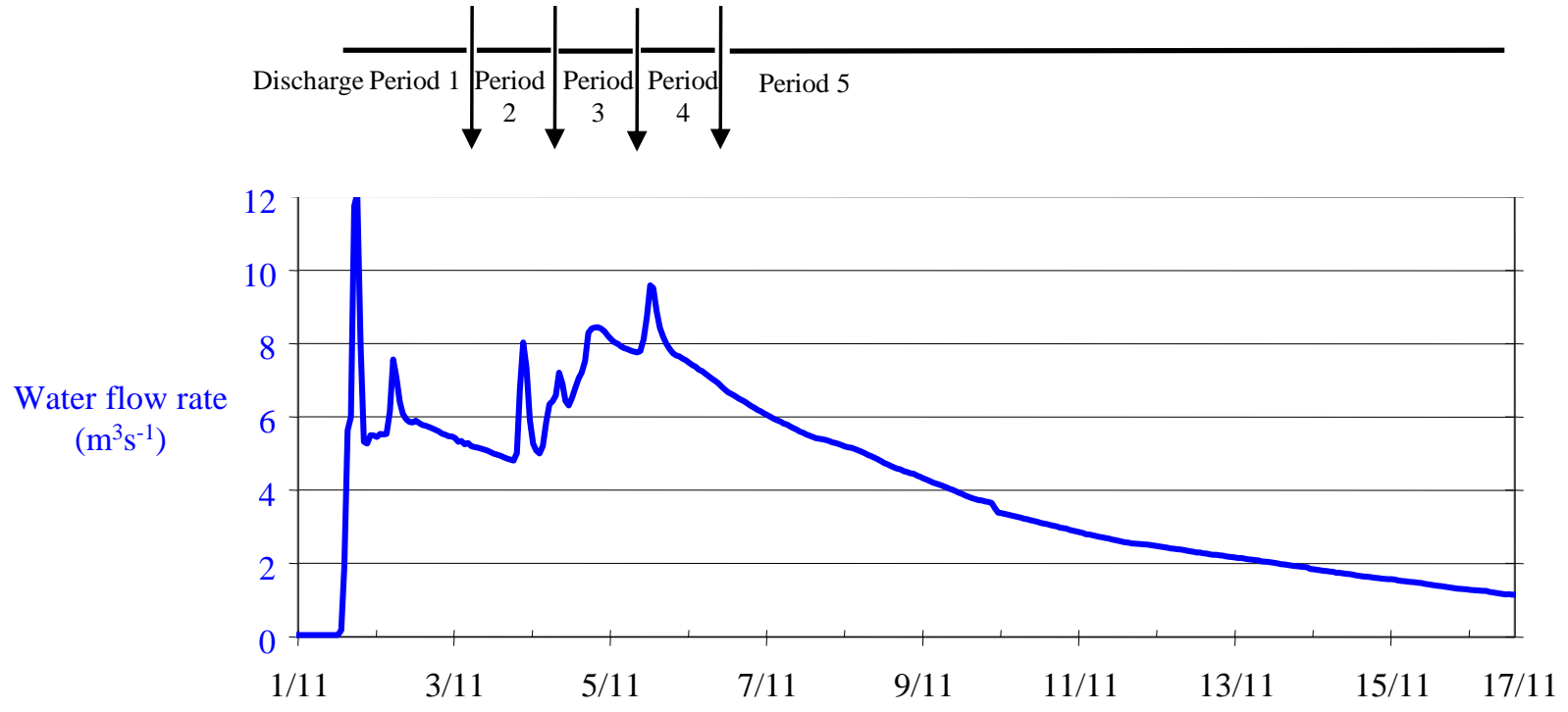

Day (November 2008)

Figure 2 
a) Particulate and dissolved matter

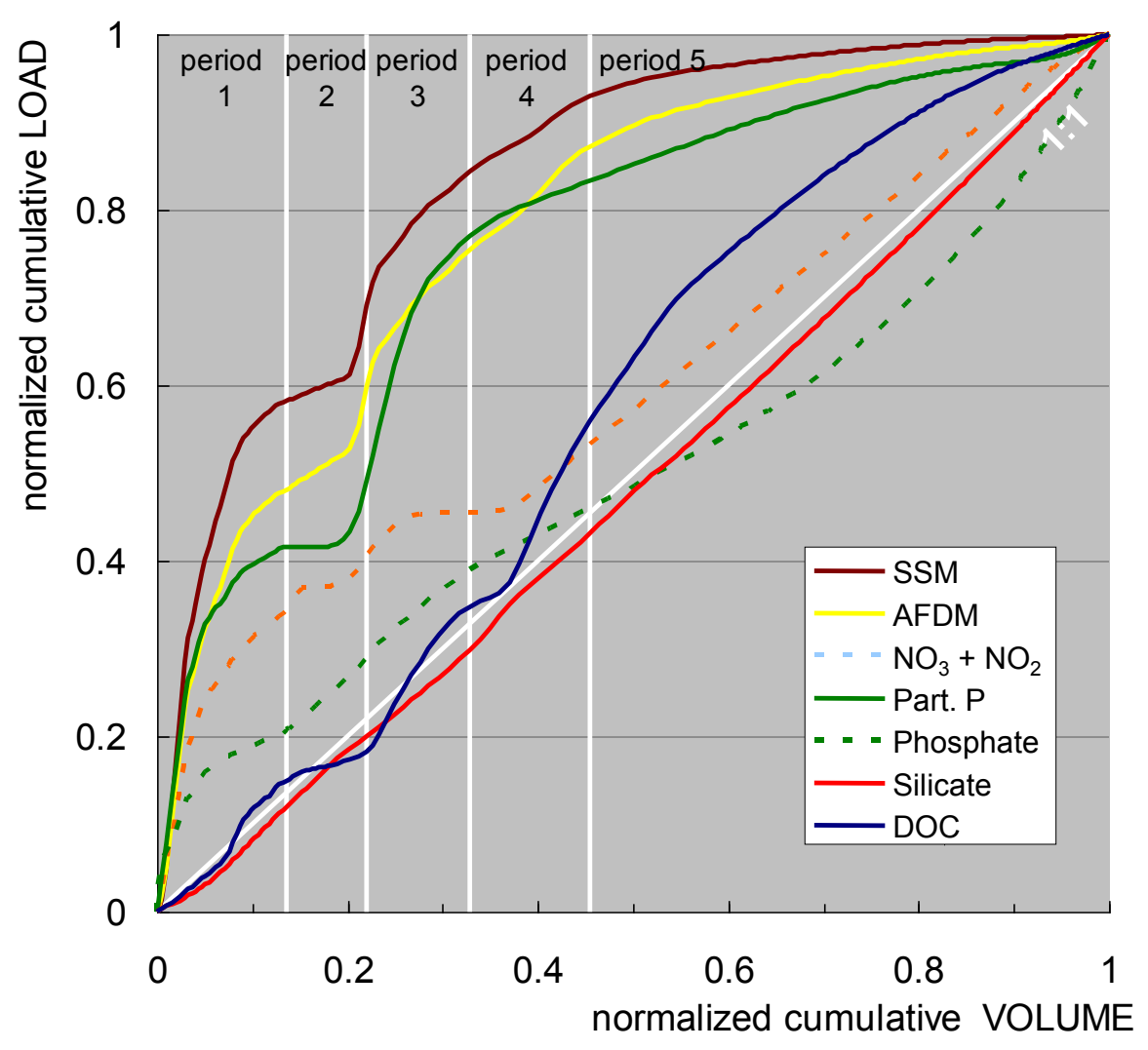

b) Dissolved trace metals

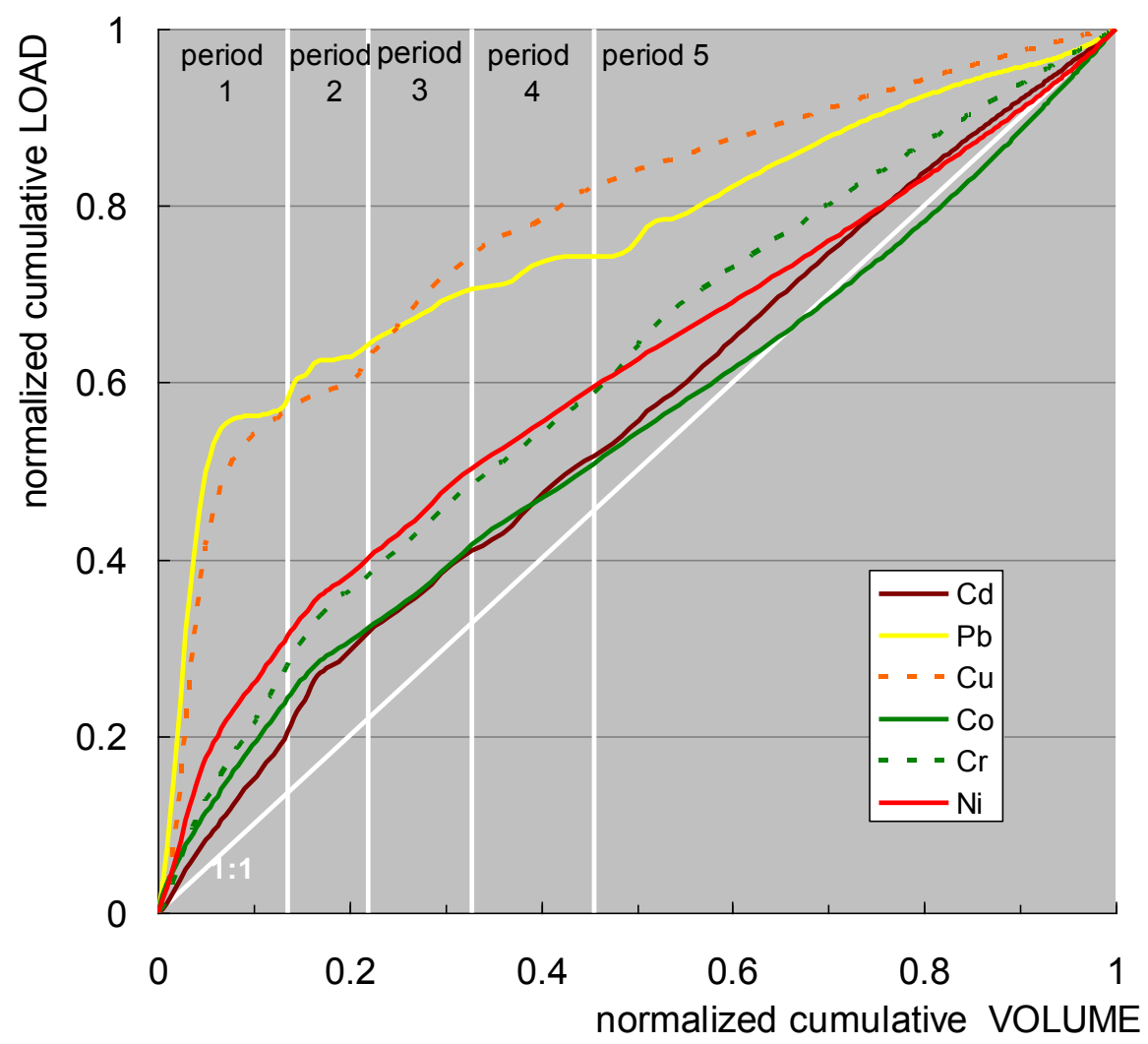


Day 1

(November $3^{\text {rd }}$ )
Day 2

(November $4^{\text {th }}$ )
Day 3

(November $5^{\text {th }}$ )
Day 4

(November $6^{\text {th }}$ )

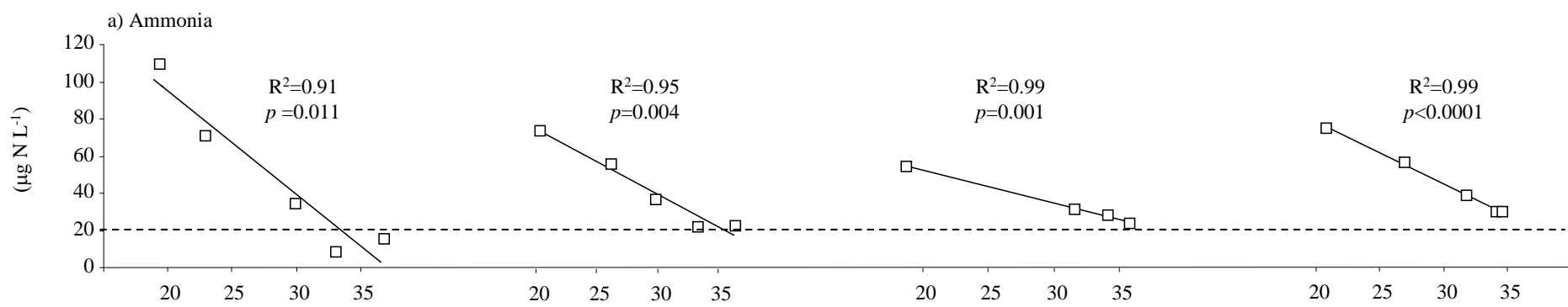

b) Nitrate
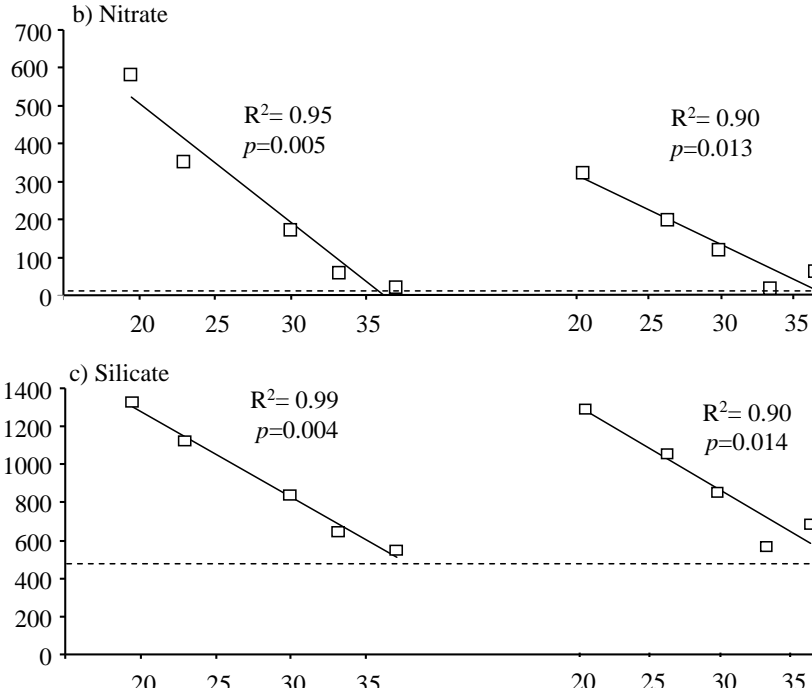

$p=0.013$

?
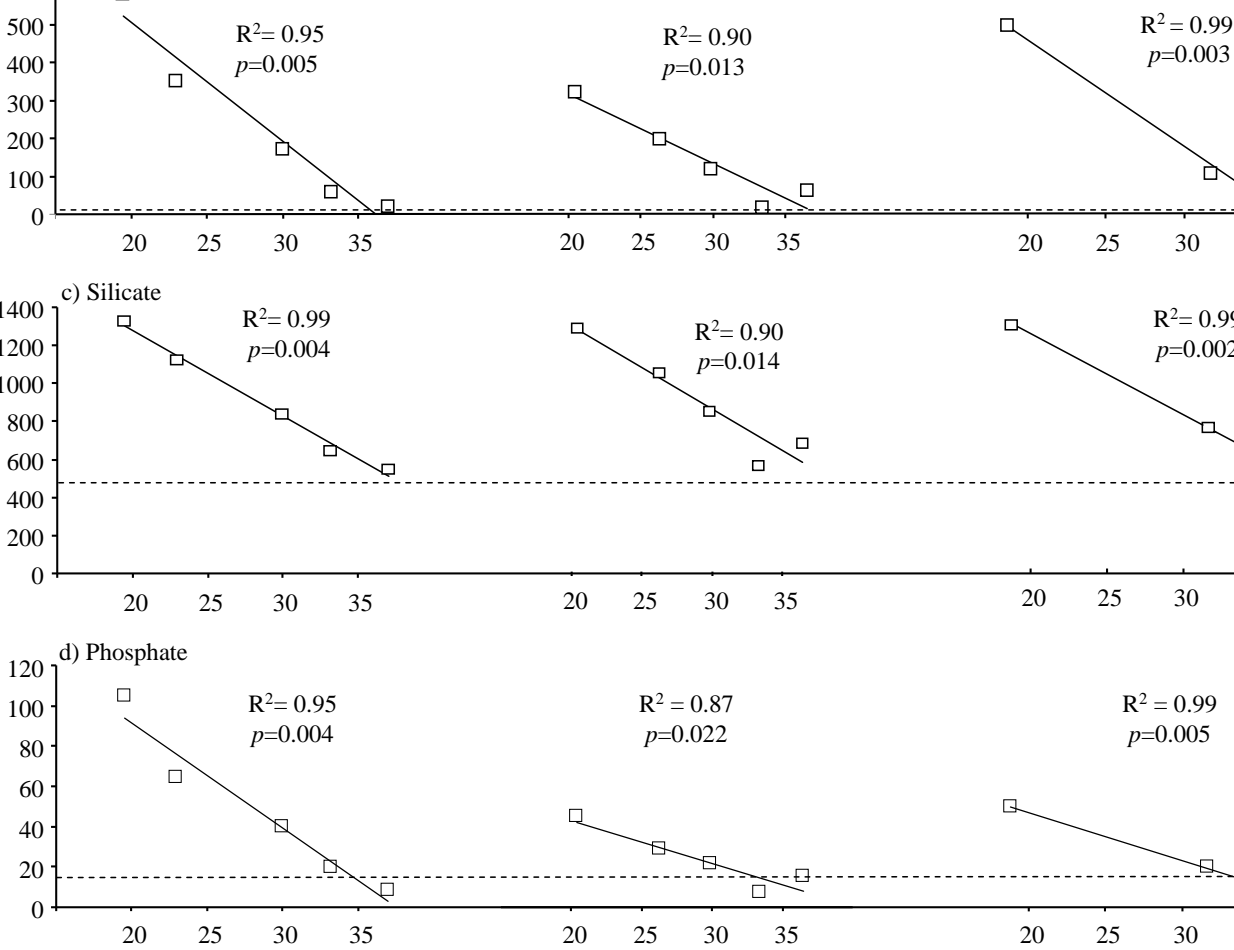

$p=0.003$
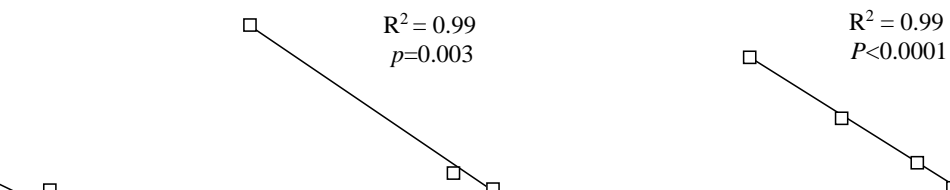

$\begin{array}{llll}20 & 25 & 30 & 35\end{array}$

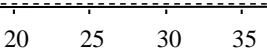




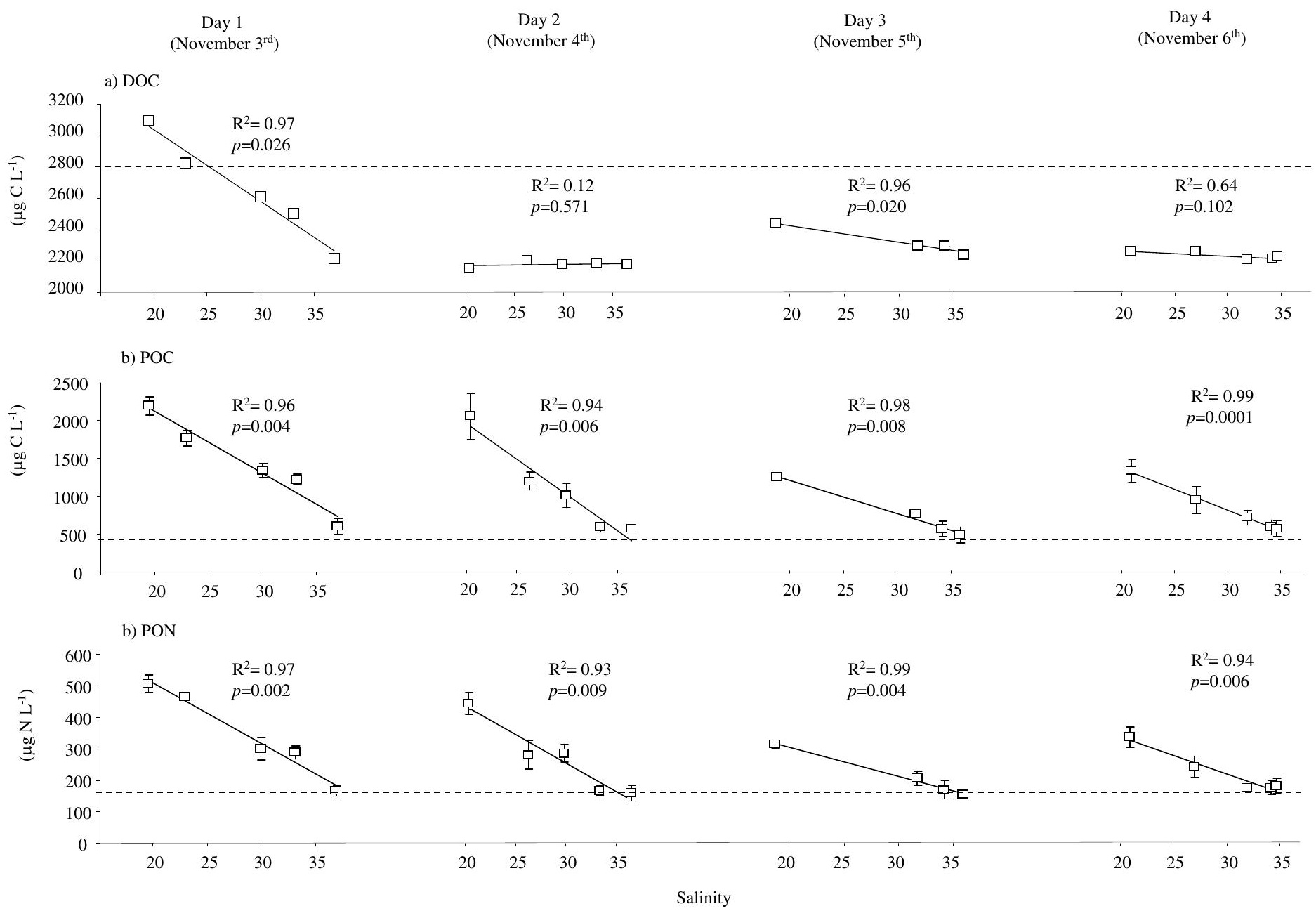

Figure 5 


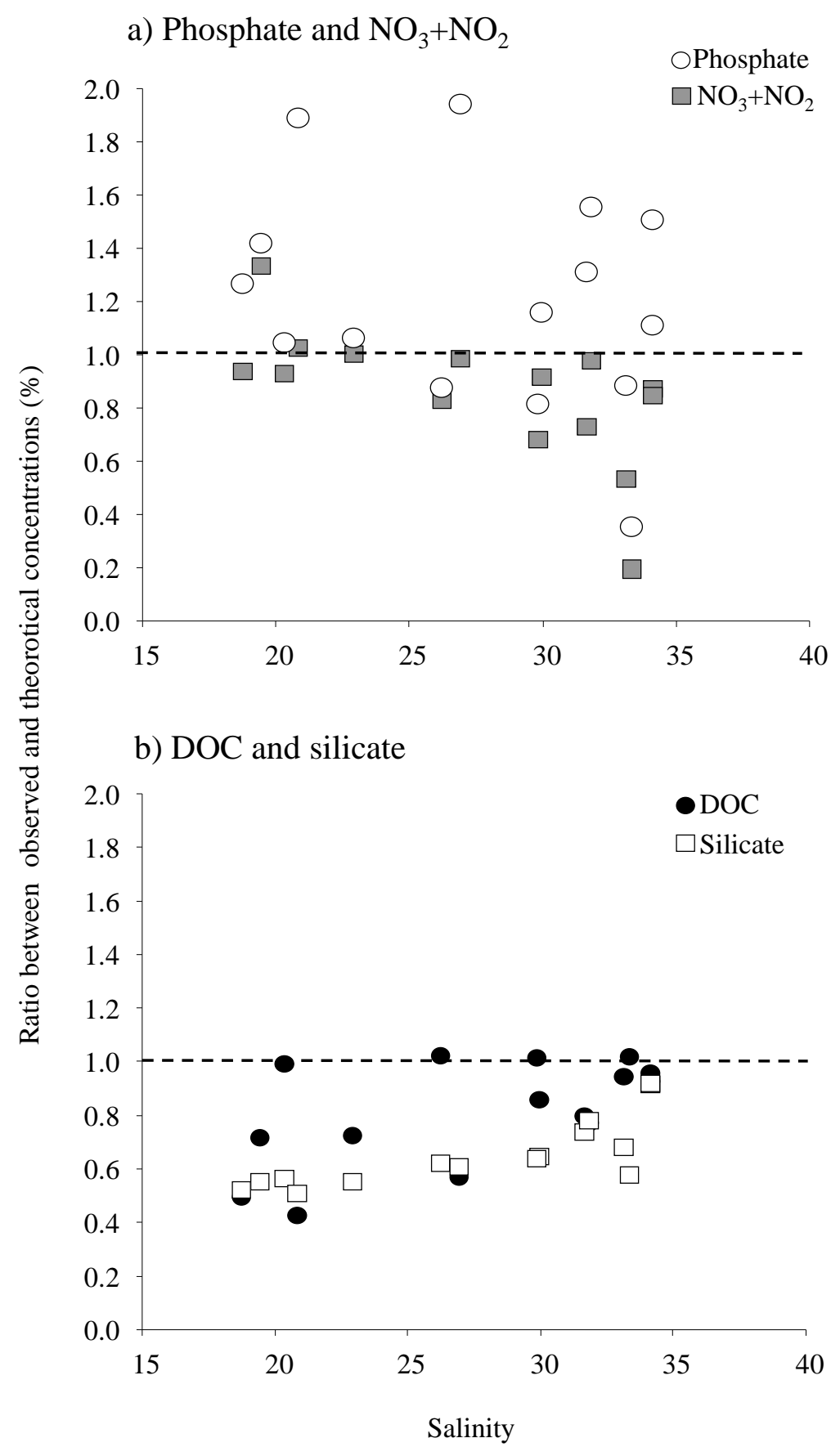

Figure 6 
Day 1

November $3^{\text {rd }}$
Day 2

November $4^{\text {th }}$
Day 3

November $5^{\text {th }}$
Day 4

November $6^{\text {th }}$ a) Phytoplankton and bacteria production rates

İ

先 9

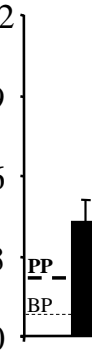

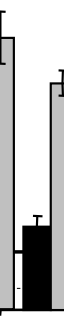

20

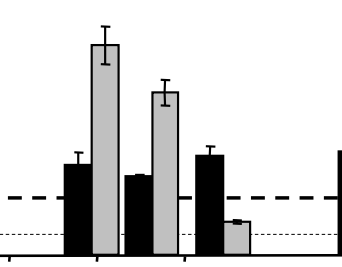

$\begin{array}{lll}25 & 30 & 35\end{array}$

b) $\mathrm{N}$ uptake rates

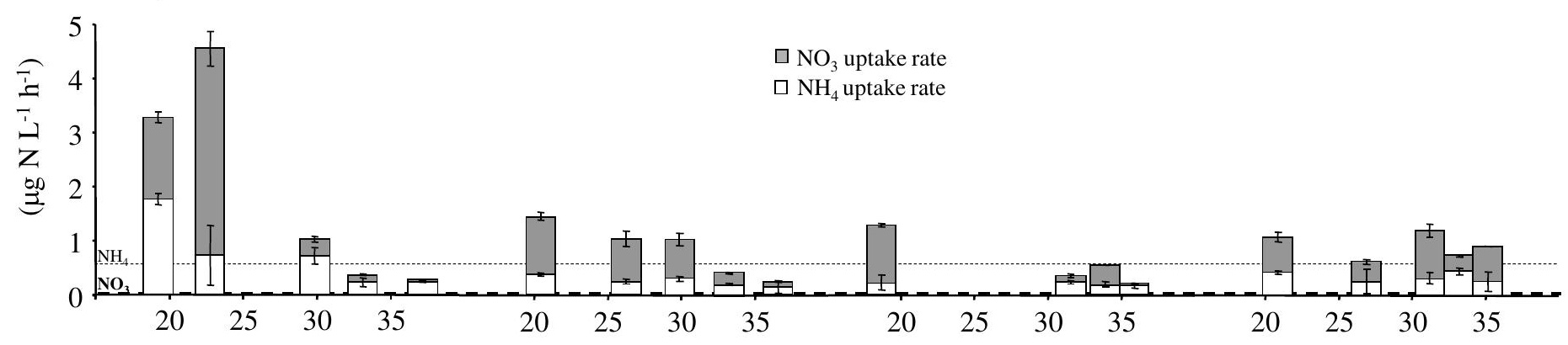

Salinity 


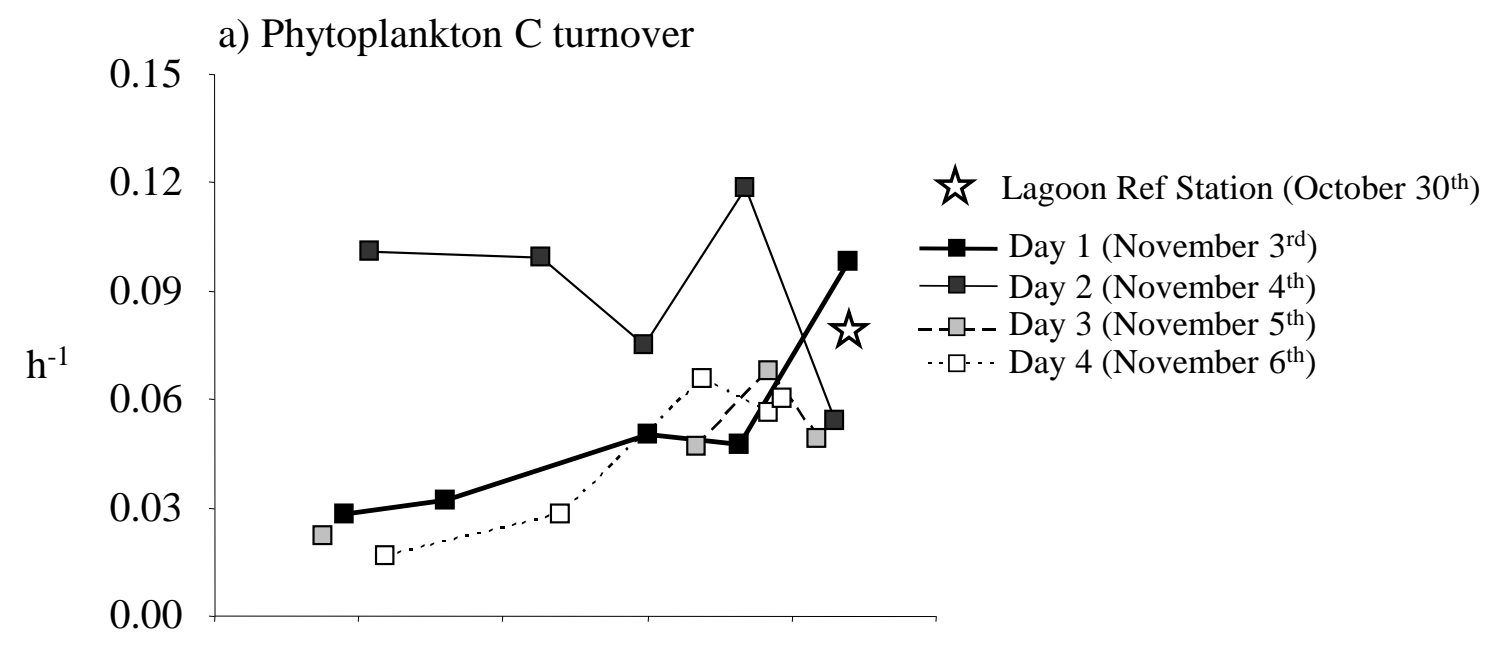

b) Bacterial $\mathrm{C}$ turnover

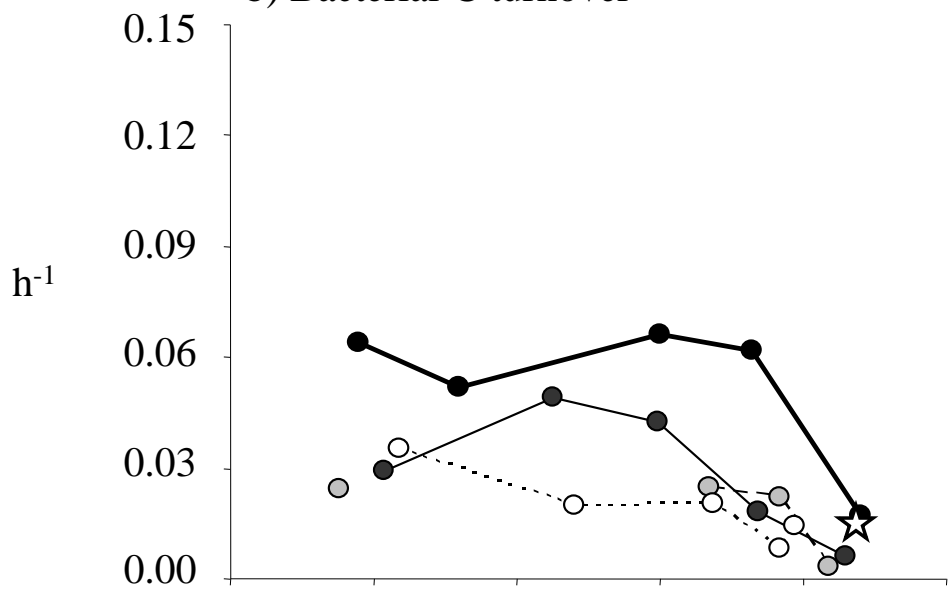

the Lagoon Ref Station (October the 30 $0^{\text {th }}$ )

$\rightarrow$ Day 1 (November $3^{\text {rd }}$ )

- Day 2 (November $4^{\text {th }}$ )

- - - Day 3 (November $5^{\text {th }}$ )

.. O.. Day 4 (November $6^{\text {th }}$ )

c) Microbial DIN turnover

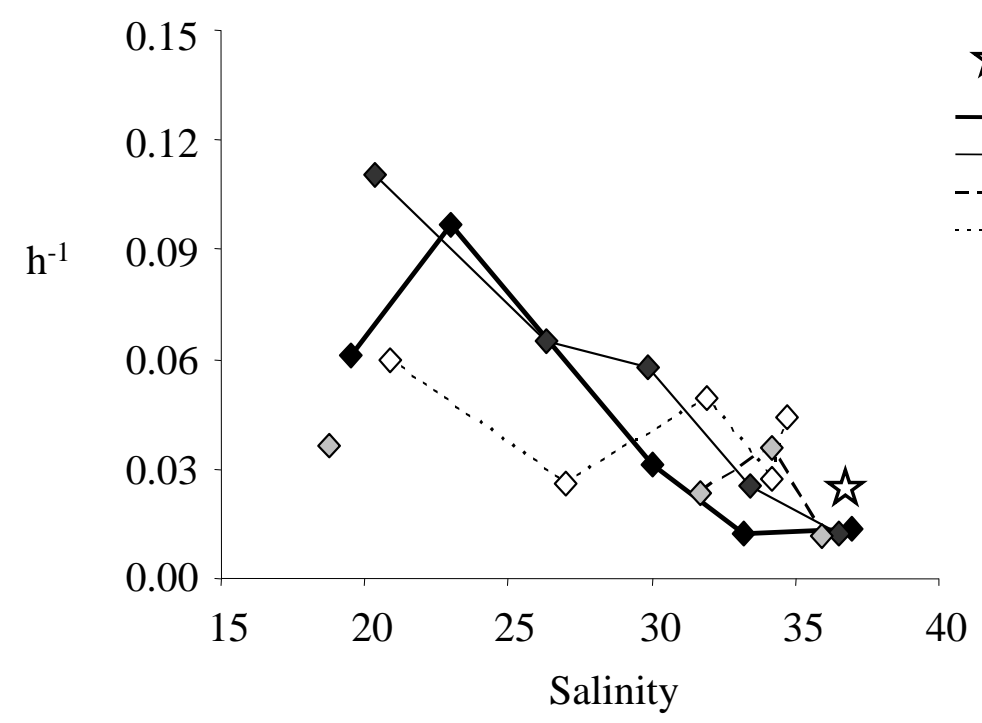

